\title{
TRADITION AND MODERNITY IN THE LITHIC ASSEMBLAGE OF MOGYORÓSBÁNYA LATE PALAEOLITHIC SITE
}

\author{
VIOLA T. DOBOSI \\ Hungarian National Museum, \\ 14-16. Múzeum krt. H-1088 Budapest, Hungary \\ E-mail:tdv@hnm.hu
}

\begin{abstract}
The time slot for Middle and Late Upper Palaeolithic (MUP, LUP) in Hungary is filled in by two large cultural phyla of the Gravettian entity, notably the blade-dominated and the pebble-dominated industries, extending through three chronological horizons. The Epigravettian cultures following the Last Glacial Maximum are not only temporal successors of the "Golden Age" in an etymological sense but can also be conceived as late, slightly impoverished descendants of the Pavlovian culture. The Ságvárian culture is partly contemporary with this blade-based Epigravettian, and successfully adapted to the same ecological conditions of the Late Würm. This industry is characterised by the pebble-working tradition, which latently survived since the Lower Palaeolithic.

Localities belonging to this entity are classified, on the basis of the priority principle, into the Ságvárian culture. The viable, strong culture existed in the interior parts of the Carpathian Basin around the last cold maximum of the Würm. The type spectrum of the tool kit fits well into the Gravettian mosaic although it is characterised by different parameters.

Its direct antecedents, time and place of its formation, the limits of extension and after-life are so far unknown. The eponymous site of the culture is Ságvár-Lyukasdomb, serving also for the stratotype of the Ságvár geochronological period.

Keywords: LGM, Hungary, Ságvárian, Mogyorósbánya
\end{abstract}

One of the current trends in the research of the European Upper Palaeolithic in the last two decades (in Hungary as early as 1990) ${ }^{1}$ was the movement of the population in the LGM period and the recolonisation of (Central) Europe after the LGM. Both the temporal framework ('after LGM') and the geographical limits (Central Europe) are based on a loose agreement by the scholars, the actual limits changing by the individual authors.

The traditional archaeological methods have to some extent been pushed into background; the reconstruction of the events is centred around chronology. The main motive is the constantly accumulating mass of radiocarbon data series. The clarification of the time sequence of localities, ${ }^{2}$ the modification/extension in the distribution scheme of cultures to the West and the North of the Carpathians is refiguring the history of Late Palaeolithic in Central Europe.

T. Terberger's recent work, compiled with abundant references, demonstrates that the area was not an "arctic desert". ${ }^{3}$ Thus the justification of the term 'recolonisation' can equally be questioned. The apparent hiatus around 19000 (calBC) is not an ultimate argument as it can simply be explained by the lack of evidence. The reinterpretation of the sequence of the Maszycka cave, used for the reconstruction of the rhythm of the settlement waves, chronology and possible routes and directions after LGM is mentioned here because the author included the site. Esztergom-Gyurgyalag in the map is spotting its possible connections with the Maszycka cave. ${ }^{4}$

${ }^{1}$ SIMÁN 1990-1991: "The intense cooling of the climate from 22.000 once more caused depopulation of the northern territories and pushed the human groups back to the periglacial in part, and the southern zone for the most part".

DOI: $10.1556 / 072.2016 .67 .1 .1$

\footnotetext{
${ }^{2}$ E.g. Wiesbaden-Ingstadt, STREET-TerberGer 1999.

${ }^{3}$ TERBERGER 2013, Fig. 23.

${ }^{4}$ KozŁowski et al. 2012, Fig. 13 .
} 
The events in the interior parts of the Carpathian Basin did not exactly fit into the general Central European 'puzzle'. This is equally valid for LGM times. First, a faunal phase was identified on the basis of the palaeontological finds of the Pilisszántó cave, described as Pilisszántó phase, which was later identified with the LGM. The synchronization of the relative time scale and the sites with older radiocarbon dates was made even more difficult as these dates were often used without proper labelling and calibration. The critical 2000 years between $\mathrm{BP}$ and $\mathrm{BC}$ dates is of crucial importance for the Late Würmian climate history. The dates are clustered in specific time phases that were considered as proofs of rhythmic settlement waves. ${ }^{5}$ The contradictions of the scanty archaeological and chronological evidences seem to get recently resolved mainly on the strength of the accumulating malacological evidences. ${ }^{6}$

Palaeontologists do not exclude the possibility that the cold maximum took place one geochronological phase later and/or it was milder than in the Western parts of Europe. The botanical data support that LGM climate was not as severe in the Carpathian Basin as on territories outside the basin. The reason can be found in the specific orographical conditions of the Carpathian Basin. The formerly supposed emptiness of the Basin can be questioned on the strength of the argument that there always existed traces of arboreal vegetation around all the settlements dated from LGM or immediately after this phase: the proximity of arboreal vegetation was always advantageous in selecting the location of a settlement. In Upper Palaeolithic sites, we have no traces of hearths operated by greasy bones. The use of bone for firing is not necessarily a consequence of natural endowments. The use of bone is a must in lack of arboreal vegetation but it can be preferred even in the case of enough potential firewood. In the Vértesszőlös Lower Palaeolithic site, where people lived within milder climatic conditions than the current times, fire was preserved with the help of broken bones. ${ }^{7}$

The Middle and Late Upper Palaeolithic (MUP, LUP) in Hungary can uniformly be characterised as the period of the Gravettian entity / Gravettian mosaic in spite of occasional differences in the material culture. Its characteristic features are as follows: identical ecological demands, the 'Gravettian landscape', ${ }^{8}$ similar settlement strategies, certain shared tool-types: backed microblades, equal ratio of end-scrapers and burins, similar raw material sources. J. Svoboda considered the "man-mammoth relationship" a decisive element of the Gravettian way of subsistence. On the basis of Hungarian evidence, this is valid only for the early phases. The last settlement where active mammoth hunting can be supposed here is Bodrogkeresztúr-Henye assigned to the Early Pavlovian, representing the Istállóskő faunal phase. The occurrence of mammoth bones, according to I. Vörös, “...on Palaeolithic settlements younger than 18-20 $000 \mathrm{BP}$ seem to be connected not with active hunting, but with accidental collecting of carcasses and bones in river-bed infilling or river valleys". ${ }^{10}$

A few Hungarian sites have received unusual attention by foreign researchers. In 2004, A. Verpoorte in his overview on the settlement history of LGM and around this time, highlighted Nadap with its 13050 (!) BP date as a proof for "late Palaeolithic recolonisation". ${ }^{11}$ Gy. Lengyel accepted this view, as well as the validity of the C-14 date supported also by sedimentological and palaeontological arguments. ${ }^{12}$ The opinion of the author is the same as expressed before, namely that a single ${ }^{14} \mathrm{C}$ date contradicting the archaeological observations is not enough to support this theory. The faunal list is irrelevant for chronological periodisation, the Rangifer-Equus-Bison triplet is known to occur in several faunal phases. ${ }^{13}$

Apart from the above mentioned Esztergom, the localities of Arka, Ságvár and the Jászság region were also grouped together on the basis of similar C-14 dates. ${ }^{14}$ Due to the apparent differences in the archaeological materials the sites in question cannot be grouped together, even accepting that the different functions of the settlements can give an explanation to certain differences. Ságvár is a general long-life settlement, a temporary hunters' camp was excavated in the Jászság area, while Arka is a workshop settlement planted right over the raw material source.

In the case of the suggested new culture names, we have to face a methodological question, namely how many sites, and how many cultural features are needed to connect the assemblages in a new cultural unit. Ságvárian, as a culture, is a well defined unit represented on several localities.

\footnotetext{
${ }^{5}$ Dobosi 1986.

${ }^{6}$ SÜMEGI 2005

${ }^{7}$ Doвosi 1990b, 519 .

${ }^{8}$ SVOBODA 2004, 285.

${ }^{9}$ Svoboda 2004, 290.
}

\author{
${ }^{10}$ VÖRÖS 2003-2004, 19. \\ ${ }^{11}$ VERPOORTE 2004. \\ ${ }^{12}$ LeNGYel 2008-2009. \\ ${ }^{13}$ Dobosi-SZÁNTó 2003. \\ ${ }^{14}$ Svoboda 2004, 465; Svoboda-NovaK 2004, Table 2.
}


According to T. Terberger's interpretation, Grubgrabian culture is also a chronological level together with contemporary Slovakian and Hungarian cultures. ${ }^{15}$ As a courtesy of F. Brandtner, I had the opportunity to see the - at that time only partially published - Grubgraben finds. ${ }^{16}$ The rich bone industry, the typical, slim, classical tool kit cannot unfortunately be connected to the coeval Ságvárian Culture in spite of the single undecorated 'baton de commandement' from Ságvár.

Also within the Carpathian Basin, the south-east Slovakian, obsidian dominated Upper Palaeolithic sites were separated as 'Kašovian' ${ }^{17}$ Due to the character of the raw material used at Kašov and Cejkov, there are many tools with cortex and, according to them, they could be regarded as the continuations of the 'pebble' tradition. The size range of the tools can be also connected to the Ságvárian. The different functions of the sites, i.e., workshop settlement vs. general habitation site cannot be ignored.

The Northern Balkan is geographically connected to the Carpathian (Pannonian) Basin. In the GravettianEpigravettian period, the connection of the Northern Balkans with the Hungarian settlements can be justly hypothesed.

This contact is mentioned in connection with Kadar, the most important site, the 'Epigravettian with shouldered points' and the 'site with classical geometrical tools': '...Because of similarities of location and characteristic of the site...Kadar is assumed to be part of a Central European cultural tradition which extended throughout the Pannonian Basin' ${ }^{18}$ Though the topographical position of the site allows the possibility of northern connections, the tool kit is seemingly closely related to the Epigravettian sites along both shores of the Adriatic Sea. ${ }^{19}$

The finds of Kadar, the key site, indicated several important assertions. Compared to the former population of the region, changes in the methods of hunting and the organisation of the groups resulted in changes of settlement strategy during the LGM. ${ }^{20}$ In the interstadial phase following LGM, the population infiltrated in the lowland lying to the north across Slovenia. ${ }^{21}$ Another possible route emerging for the population of the Balkans after the LGM can be hypothesed along the Danubian corridor towards the south. ${ }^{22}$ Both of these otherwise opposite directions touch the current territory of Hungary. So far none of the theories are supported by Hungarian finds and the conclusive geometrical microlithes are altogether missing.

\section{ANTECEDENTS}

Pebble-based technology is a long-lasting alternative for core-technology in the processing of lithic artefacts. It is present in all the three phases of Hungarian Palaeolithic. These phases include the Lower Palaeolithic site of Vértesszőlös, the middle Palaeolithic sites Tata and Érd, all of them settlements of special importance, and also an individual cultural entity within the Upper Palaeolithic termed after the Ságvár site as 'Ságvárian'. The utilisation of pebble (and non-pebble) raw materials (from boulders, nodules, laminar or bed-form raw material occurrences and/or exploitation sites) is never exclusive. Intact (manuports) or split (worked) pebbles are probably present in all Palaeolithic sites though they are not always mentioned in the publications. At the same time, there are always certain percentages of tools made of non-pebble raw materials in the so-called pebble-based industries. A few kilometres from the site, we can find radiolarite outcrops that were subsequently fragmented and used. We cannot unambiguously decide for or against a pebble origin in case of objects without pebble cortex.

In our understanding, pebble-based industries have the following features:

- the ratio of standard and non-standard tools made of pebbles (containing observable pebble cortex) is high $^{23}$

- the average length of the tools is between $30-40 \mathrm{~mm}$,

- the character of the industry is typically bulky with low laminarisation values, the width-length ratio is about 1:1.75 (the minimal value for blades is 1:2)

- formal criteria arising from the elaboration of spherical pebbles are observable (e.g. for Upper Palaeolithic artefacts, the high dorsal relief gives a pseudo-aurignacoid character).

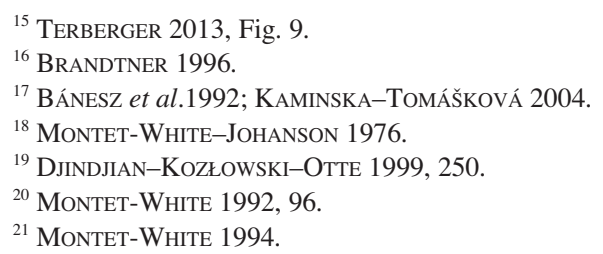

${ }^{22}$ Minajlović-Minajlović 2013.

${ }^{23}$ The mass of the non-standard tools nearly reaches or occasionally surpasses the half of typical tools' mass: $52 \%$ at Vértesszőlős, $57 \%$ at Tata and $45 \%$ at Mogyorósbánya. If we take the pebble-derivates out from the typical tools (e.g. side scrapers made on segment), the ratio is higher. 


\section{Vértesszölös}

Six cultural layers and several find spots were found on the territory of the ancient Vértesszőlős limestone quarry in the area of the two archaeological locations with altogether 3071 non-standard and 5819 standard tools. $^{24}$ The standard tools were assigned by László Vértes, on the basis of formal criteria, into 50 types. These fifty types do not necessarily imply the same amount of different functions; however, effective traceological studies were not performed on the material. The raw material of the artefacts was collected from the redeposited gravel bed terraces of the Átalér stream. ${ }^{25}$ The ratio of the two major raw material type categories, i.e. quartzite and different silices, is different in the various tool type categories. In the case of the Lower Palaeolithic types (the chopper-group) the ratio of quartzite surpassed 70\%. In the upper cultural layers the quantity and size of the tool types of an Upper Palaeolithic character increase with a likewise increasing ratio of silex utilisation. These trends reflect the interior development of the lithic industry of the communities periodically returning to the same settlement.

The technological parameters of the lithic industry can be considered standardised. The average length of the typical tools is 28.12 (!) $\mathrm{mm}$; the width to length ratio is $1: 1.756$, i.e. the length hardly surpasses one and a half times the width of the artefacts. ${ }^{26}$ The selection of the pebbles suitable for tool production, the formation of the base form and the subsequent finishing of the artefacts required considerable manual skills and well co-ordinated, planned activities. Using the tiny tools indirectly must have taken large efforts. The supposed potential functions (butchering large animals, working on hide, timber and splitting bones) are unlikely to be efficient in this (indirect) form. The construction of composite (i.e. hafted) tools, if we can find ample proofs, would be a most remarkable innovation. There have, however, no specific studies been made on this aspect as yet.

The dating of the site and the individual settlement levels varies between extreme values. Based on the fauna and the flora, which is the eponymous unit of the Vértesszölös faunal phase, the age of the site can be assigned to the Mindel II-Mindel/Riss interglacial period. ${ }^{27}$

Magnetostratigraphy: magnetostratigraphical evidence dates the site, together with Tata, into the younger phase of limetuff formation in Hungary. This period started in the so-called Jaramillo chron and terminated in the reversed polarity phase of the Brunhes period. ${ }^{28}$

'Absolute' chronology

The existing data are varied.

The method is unknown: the travertine overlying the cultural layer 250-457 kyear ${ }^{29}$

The age of the travertine by $230 \mathrm{Th} / 234 \mathrm{U}$ method:

Travertine covering the palaeolithic settlement $>350$ kyear $^{30}$

Absolute age for the cultural layer185-210 kyears ${ }^{31}$

\section{Tata-Porhanyó}

This site can be considered a much younger descendant of Vértesszőlös, with several geochronological phases in between them:

- the settlement conditions are very similar in the two localities lying within an eyeshot from each other: settled in temporarily dry limetuff basins partly surrounded by limetuff walls,

- similar, or even identical raw material sources,

- close values in the technical parameters of the tool kit,

- ratio of non-standardised tools.

${ }^{24}$ Dobosi 1990a, 311.

${ }^{25}$ VARGA-MÁTHÉ 1990, 292.

${ }^{26}$ Dobosi 1990, 365-366.

${ }^{27}$ JÁnOSSY 1990, 14; László Kordos assigned the Vértesszőlős faunal phase into the Holstein period: KoRdos 1994.

${ }^{28}$ KorPÁs 2003, 142. Moreover, in his report for the National Science Grant (T 30107) 1999-2002 Korpás assigned the Vértesszőlös and Tata cultural layers to the interval between the

\footnotetext{
Matuyama chron $\mathrm{C} 1 \mathrm{r}$ and the Brunhes chron $\mathrm{C} 1 \mathrm{n}$ anomaly; Vértesszőlős was estimated for 1.1 Myear \pm some kyears.

${ }^{29}$ Cherdintsev-Kazachevski 1990, 547

${ }^{30}$ OSMOND 1990, 545.

${ }^{31}$ SchwarcZ-Latham 1990, 549. There is an 800 kyear gap between the extreme values on the possible dating of the site, which is two times more than the most probable (geochronological) dating of the site. The chronology of the Vértesszőlös site needs a strict revision considering the temporal limits.
} 
On the current level of elaboration, the Middle Palaeolithic site of Tata-Porhanyó yielded - starting from the first excavations by T. Kormos in 1909 - 2937 typical tools and 1695 non-standard artefacts with more than 40,000 flakes larger than $5 \mathrm{~mm}$.

The distribution of the typical tools by type groups is the following:

\begin{tabular}{|c|c|c|c|c|c|}
\hline \multicolumn{2}{|c|}{ Lower Palaeolithic types } & \multicolumn{2}{c|}{ Middle Palaeolithic types } & \multicolumn{2}{c|}{ Upper Palaeolithic types } \\
\hline pieces & $\%$ & pieces & $\%$ & pieces & $\%$ \\
\hline 183 & 6.23 & 2222 & 75.65 & 532 & 18.11 \\
\hline
\end{tabular}

The average length of the artefacts is $36.6 \mathrm{~mm}$, some $8 \mathrm{~mm}$ longer than at Vértesszőlős. The width/length ratio is $1: 1.729$, i.e. the industry is definitely bulky and the level of laminarisation is low.

The distribution of the raw material used for the tools is the following: radiolarite $27 \%$, quartzite $30 \%$, other siliceous raw materials $41 \%$.

Chronology:

In 1964, two radiocarbon dates were known from Tata:

Gro 2538:50000 \pm 2500

GRN 3028:33600 $\pm 1100^{32}$

Miklós Gábori and Vera Gábori-Csánk obviously supported a ,short” chronology based on radiometric dates and determined the chronological order of the Hungarian Middle Palaeolithic and the position of the other sites, especially Érd, accordingly. ${ }^{33}$

Later, in 1982, new and much older dates made by $230 \mathrm{Th} / 234 \mathrm{U}$ method were published.

Dating was accomplished for the "travertines deposited in the spring" enclosing the cultural layer. For the underlying layers, it yielded $120 \pm 6$ kyears and for the overlying horizon a value of $78 \pm 5$ kyears was gained, thus the age of the cultural layer was estimated to $99.4 \pm 0.1$ kyears. $^{34}$

Currently, the climatic phase Eem, OIS $5 \mathrm{c}$ is considered as a valid dating for the site.

This date is consolidated by Arvicolidae-stratigraphy. ${ }^{35}$

Érd: The archaeological finds were elaborated with a different methodology, so we have no possibility for a direct comparison.

The raw material of the tools was collected from a gravel bed situated about 500 meters from the site. It comprised $74 \%$ quartzite, the remaining $26 \%$ contained various silices from different geological periods, like Jurassic radiolarite, Eocene andesite tuff, Triassic hornstone. ${ }^{36}$

There were 789 tools reported from the site by V. Gábori-Csánk. $76 \%$ of the tools were scrapers, most of them simple side-scrapers with straight, arched or concave edges. As the author observed, most of the tools were made on rounded quartzite pebbles:

"Une caractéristique de l'industrie est que les outils sont tailllés sur galets roulés, pour la plupart de quarzite. La technique est analogue à celle du Moustérien-pontinien... Par suite de la forme et de la dimension de la matière première, les éclats et les outils sont souvent couverts de cortex". ${ }^{37}$

The dimensions grouped by size ranges are presented in the publication. The most frequent dimension range according to the data and the presented illustrations is between $50-60 \mathrm{~mm}$. According to the technical and typological features, the lithic industry was assigned into the Charentian cultural complex:

"Après les analyses technique et typologique, nous trouvons que l'industrie d'Érd peut être appelée un Charentien d'Europe sund-orientale pris au sens large." 38

${ }^{32}$ VRIES-WAARD 1964, 35-36.

${ }^{33}$ GÁBORI-CSÁNK 1968, 109; GÁBORI 1976, 216.

${ }^{34}$ SCHWARCZ-SKOFLEK 1982, 590.

${ }^{35}$ Kordos-Ringer 1991, 526; "Following the climatic optimum $5 \mathrm{e} /$ Eem, there is a slight decrease of temperature $(5 \mathrm{~d})$ followed by a new phase of warming, the so-called $5 \mathrm{c}$ climatic zone dated be- tween 104-96 kyears. In the fauna, the dominance of Microtus arvalis was returning, Lagurus became constant and the frequency of Myodes increased why the density of Arvicola decreased".

${ }^{36}$ DiENES 1968, 111-112.

${ }^{37}$ GÁBORI-CsÁNK 1968, 273.

${ }^{38}$ GÁBORI-CsÁNK 1968, 274.

Acta Archaeologica Academiae Scientiarum Hungaricae 67, 2016 
site. This phenomenon was repeated several times in the history of Hungarian Palaeolithic archaeology. For example, the 'Transdanubian Szeletian' was transformed into the Jankovichian culture ${ }^{48}$ after the excavation of the Remete-Upper cave, and following the excavation of the open-air settlements in the Danube Bend region, the socalled Pilisszántó culture was incorporated into the Epigravettian circle. ${ }^{49}$

The revision of the Ságvár geochronological period and parallel to this, the chronology of the Hungarian LGM period and their connection to the archaeological localities, refuting or corroborating former opinions, is very topical again on the basis of new wide-scale natural scientific observations. Namely, the older horizon of the period (represented by the lower cultural layer of Ságvár-Lyukasdomb) did not show humification at Mogyorósbánya and even the malacofauna did not show interstadial conditions for this level of the settlement. Thus the widely published Tápiósüly h1 and $\mathrm{h} 2$ soil formation periods ${ }^{50}$ connected to the beginning and closing interstadial phases at Ságvár and observed all over the Carpathian Basin, have to be re-interpreted.

The synchronisation of geomorphological and archaeological data within Hungary seems to promise more success than correlation with Western European terminology. Immediate connection to the climatic curves delineated on the basis of GIS cycles is far from the current realities. ${ }^{51}$ It seems settled, however, that the upper cultural layer spotted at the depth of $1.4 \mathrm{~m}$ at Ságvár corresponds to the humus level of the Ságvár-Lascaux interstadial, i.e. the Tápiósüly h1 palaeosoil horizon. ${ }^{52}$

In 1994, S. K. Kozłowski used the term "Ságvárian" as a synonym for Hungarian Late Palaeolithic. ${ }^{53}$ This generalisation was adopted in more recent papers as well. ${ }^{54}$

\section{THE SÁGVÁRIAN ENVIRONMENT}

\section{Orography}

In the Upper Pleistocene, there is no sign of a large-scale surface transformation in the Carpathian Basin. The arch of the high mountains encircling the basin in about two thirds of its extent flattens towards the central parts to the level of mid-mountains (max. elevation 1000 metres a.s.l.) and then, with a range of low-lying hills, they blend into the lowlands. Minor tectonic movements, erosion regulated by the changing relief energy and the rivers with fluctuating water discharge formed a system of climatic terraces. Only the relict glacial elevations or the marginal loess zones of the lowlands were suitable for habitation on the lowlands covered temporarily with waters.

In the stadial periods of the pleniglacial phase, the basin was closed from the east-northeast with the exception of a few river valleys (e.g. Maros river). From the North-West, the Danube valley offered an ideal route toward the interior parts of the basin. The movement of the faunal waves and the human populations starting from the Eastern European centres (with shouldered blade points, mammoth huts and mobile art) is delineated by a row of sites in a corridor between the Carpathians and the terrestrial ice sheet.

\section{Vegetation}

The series of investigations of the Hungarian loess profiles and the foothill region of the Kopasz-hill at Tokaj brought about important results in the Pleistocene climate history. These studies were partly directly connected to Palaeolithic settlements (Madaras, Szeged, Jászfelsőszentgyörgy); on the other hand, the environs of Tokaj is a thoroughly investigated area with favourable natural endowments, one of the centres of the Older Blade industry / Pavlovian culture. ${ }^{55}$

The macro- and microfossils show the mosaic-like character of the vegetation and the constant presence of forestal refugia. The survival of these habitats was explained by M. Járai-Komlódi by the favourable micro-regional conditions (southern slopes, proximity of rivers and springs).

In the stadial periods, the flora of the lowland (Alföld, Great Hungarian Plain) was characterised by non-arboreal loess steppe and coniferous forests. In more humid periods, Larix decidua, within milder cold periods Picea abies were the typical forest components.

\footnotetext{
${ }^{48}$ GÁBORI-CsÁNK 1983.

${ }^{49}$ Dobosi 2006.

${ }^{50}$ HAHN et al. 2002, Fig. 3.

51 Terberger 2013.
}

\author{
52 SÜMEGI 2005, 104. \\ ${ }^{53}$ KozŁowsKi 1994, 132. \\ ${ }^{54}$ E.g., DJinduian et al. 1999, 235. \\ ${ }^{55}$ Bodrogkeresztúr-Henye, DoBosi 2000. \\ Acta Archaeologica Academiae Scientiarum Hungaricae 67, 2016
}


The arboreal vegetation was dominated by the ecologically tolerant, light demanding Pinus silvestris. The non-arboreal vegetation was dominated by Chenopodiaceae and Artemisia species, with a large quantity of Poaceae pollen that is believed to be a specific feature in Hungary. ${ }^{56}$ In the interstadial phases, the forests could recover relatively fast from the refugia. Forestation took place in two phases between/around 22000 and 18000 , respectively. LGM is dated in between these dates, the exact synchronisation with the radiocarbon dates is a problem for further considerations. ${ }^{57}$ The vegetation of the interstadial of the Late Upper Palaeolithic comprised forest-forming species of the modern temperate zone (QUT, Fraxinus), and there are many hydrophytes among the non-arboreal plants. Carpinus, Salix and Betula are known to occur in the riparian gallery forests or in mixed forests, together with conifers. ${ }^{58}$

\section{Fauna}

Malacofauna (grouped by BP data)

The malacological analysis of 24 Hungarian loess profiles resulted a malaco-chronological scheme. ${ }^{59}$

25-22 Kyear BP: following the great interpleniglacial, the species list for the zonula Vallonia tenuilabris indicated stadial, cold-continental steppe conditions. There is no archaeological locality assigned to this phase as yet.

22-20 Kyear BP: a milder and more humid phase with mesophilous fauna with a great ecological resistance known as Vallonia costata zonula (the older humic horizon from Dunaújváros-Tápiósüly with the h2 embryonal soil ${ }^{60}$ )

20-18 Kyear BP Würm cold maximum: cold continental steppe with the Columella columella zonula. On the northern slopes of the Tokaj hill, the average July temperature could be around $11-13{ }^{\circ} \mathrm{C}$. ${ }^{1}$ This phase is represented by the Mogyorósbánya archaeological sequence. The Mogyorósbánya cultural layer yielded species with a great ecological resistance. Species indicating cold climate (Columella, Vallonia), and species preferring mild climate (Chondrula, Helicopsis) were equally found; the most frequent taxon, comprising $36 \%$ of the malacofauna is the cold resistant species Succinea oblonga, preferring a humid environment. ${ }^{62}$

18-16 Kyear BP: Relatively milder humid period with the marker species Vestia turgida-Punctum pygmaeum. This period corresponds to the younger humus horizon of the Tápiósüly-Dunaújváros h1 soil level.

\section{Large mammals}

LGM in Hungary is represented by the faunas of 22 cave sites and 10 open air habitation sites. The eponymous site is the upper cultural layer of the Pilisszántó rock shelter. Apart from the specifically 'cold' microfauna, the most frequent large mammals are anthropogeneous elements at the sites, i.e. remains of hunted animals. The dominant species is Rangifer. It is missing from only 7 sites. The second in frequency is Equus, followed by Bison and, in mountainous-forestal (!) environment, Cervus and Sus. ${ }^{63}$

The 'l'âge du renne' in the Carpathian Basin is mainly valid for the Transdanubian areas. To the East of the Danube, horse was equally important prey animal as reindeer.

At Ságvár, the fauna is composed of Rangifer, Equus, Castor while at Madaras only Equus was identified.

Research concerning the seasonality of the settlements is hindered by the extremely bad conditions of bone fossilisation. On the Great Hungarian Plain (Alföld), egg shells at Madaras (Ságvárian) and in the Jászság area (Epigravettian) indicate late spring for the temporal limits of the settlements. ${ }^{64}$

Though the season for hunting herbivores and carnivores, respectively, could be typically different, the bones of predators also appear in a low number in the contemporary open-air hunting camps. From the coeval sites of the Pilismarót environs, practically the complete macrofauna spectrum is known: Canis, Gulo, Vulpes, Rangifer (dominant), Bison, Equus, Sus, Lepus. ${ }^{65}$

During the seasonal migration of reindeer, the herds of animals congested at the shallows of the Danube, they attracted the predators, and the ratio of carnivores/herbivores on the archaeological sites is selectively distorted to $1: 400 .^{66}$

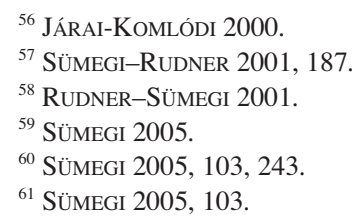

${ }^{62}$ Krolopp 1992, 17.

${ }^{63}$ VöRÖs 2000, 200-201.

${ }^{64}$ VÖRÖS 1993.

${ }^{65}$ VÖRÖS op.cit

${ }^{66}$ M. KRETZOI, personal communication. 


\section{MOGYORÓSBÁNYA, THE SITE TOPOGRAPHY, STRATIGRAPHY, SETTLEMENT FEATURES}

Mogyorósbánya is located on the Northern margin of the Gerecse Mts., administratively in KomáromEsztergom county. The two decisive landscape features here are the $457 \mathrm{~m}$ high Gete hill, the easternmost individual member of the Gerecse Mts. and the vertical rock wall of the Öreg-kő ('Old Stone') at Bajót. The Late Pleistocene terraces of the Danube to the west of the Dorog basin are separated from the current bed of the Danube by a wide alluvial plain, dissected by the right side tributaries of the river.

The Palaeolithic settlement was located on a hill top of $208 \mathrm{~m}$ a.s.l. on the left side of the Mogyorósi stream (Fig. 1) sloping slightly towards the south-west, with a direct view on the Jankovich cave (Fig. 2) and Gete, and the northern part of Gerecse in the East. (Fig. 3)

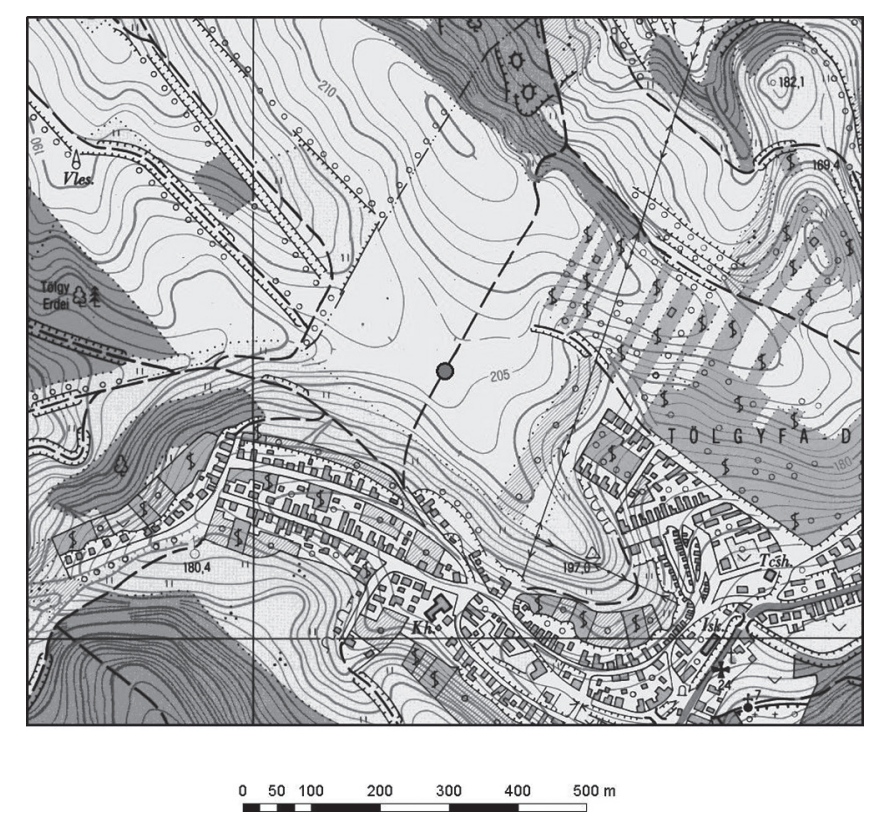

Fig. 1. Topography of the site (map by B. Holl)

During the Holocene, the surface of the terrace was spectacularly levelled by erosion. The eroded humus has accumulated in the depressions.

During the excavations, three settlement patches were uncovered: Spot I at $204 \mathrm{~m}$ a.s.l., extending over 40 $\mathrm{m}^{2}, 25 \mathrm{~m}$ to the west of Spot I we can find Spot II extending over $30 \mathrm{~m}^{2}$, further on, $45 \mathrm{~m}$ towards NNW Spot III lies at $206 \mathrm{~m}$ a.s.1. extending over $300 \mathrm{~m}^{2}$.

On the SSE exposed slope, loess accumulated in a thickness of minimum 2 meters. The cultural layer became wedged by the margin of the terrace, on the northern edge of the IIIrd settlement spot it is $170-180 \mathrm{~cm}$ below the current surface. (Fig. 4) In the section, the habitation surface appeared in an almost fully horizontal position in a 5-8 cm thick stripe, which was darker than its embedding environment. It could clearly be followed in the loess. The section taken at the corner of the IIIrd settlement spot was analysed by Zs. Ruszkiczay-Rüdiger. Under level A and level B of the recent soil, we can find macroscopically homogeneous pale yellow typical loess with a high carbonate content. $50 \mathrm{~cm}$ over the cultural layer, the secondary carbonatic precipitation (lime mycelia) became more frequent, indicating very dry climate with steppe vegetation. ${ }^{67}$

\footnotetext{
${ }^{67}$ RUSZKICZAY-RÜDIGER 2011.
} 


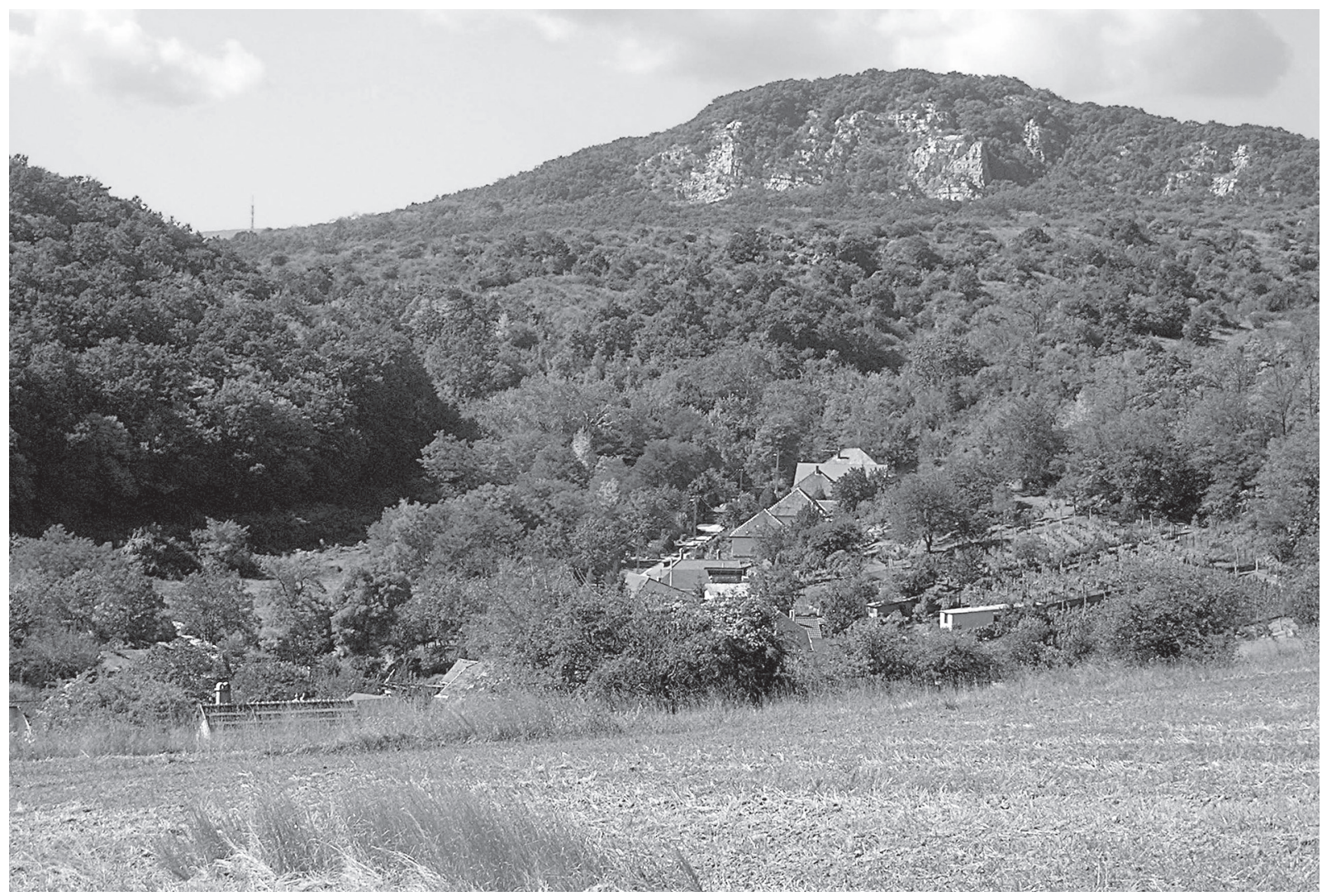

Fig. 2. Mogyorósbánya, site on the terrace rim, in the background the limestone wall hiding the caves with Middle and Upper Palaeolithic layers

The topographical position of the Ságvárian sites does not suggest a culture-specific pattern. The structure of the settlements is rather complex: at Ságvár, two cultural layers and a semi-subterranean residential hut ${ }^{68}$ at Mogyorósbánya, at least three habitation units in the form of oval concentration of finds separated by sterile stripes. At Szob, the large settlement surface comprised a fireplace surrounded by 11 andesite blocks and three heaps of fossil molluscs of a diameter of $20-25 \mathrm{~cm}$ and a height of $14-16 \mathrm{~cm} .{ }^{69}$ At Madaras, several large hearths of a ringlike structure were found, which can be interpreted as signs of a long-lasting settlement.

Mogyorósbánya is a general/seasonal settlement without structures (hut, tent, pit, bone concentration) but with various functions: heavily burnt patches of fireplaces, kitchen debris, production and rejuvenation of tools. There are artefacts representing a wide typological spectrum here, as well as mineral paint (ochre) and trinket snails among the finds. On the basis of the proximity of the settlement patches and their arrangement, we suppose coeval habitation, the actual proofs of which (e.g. refitting pieces from different habitation spots) can only be expected after the detailed analysis of the finds.

The cultural layer is not very intensive but occasionally of a large extent. Spot no. III is as large as $300 \mathrm{~m}^{2}$, and it is not yet fully uncovered. This feature is also characteristic of other Ságvárian settlements. The settlement has a single cultural layer. On the loose surface covered with scanty vegetation, vertically or obliquely embedded bones and stone tools often cover the walking surface. The fauna is in a poor state of preservation, it comprises split and broken bones, kitchen debris with occasional teeth or jaw fragments.

The hearths are of various sizes and irregular shapes, unevenly burnt with charred and ashy spots as typical of open-air hearths. The largest one is about $1 \mathrm{~m}^{2}$. One feature was identified as a hole for keeping cinder; it had a depth of $15 \mathrm{~cm}$ and a diameter of $35 \mathrm{~cm}$, a hole with rounded bottom filled with ash, charcoal and heavily burnt bone fragments.

${ }^{68}$ GÁBORI-GÁBORI 1957.

${ }^{69}$ MARKó 2007, 9At. 


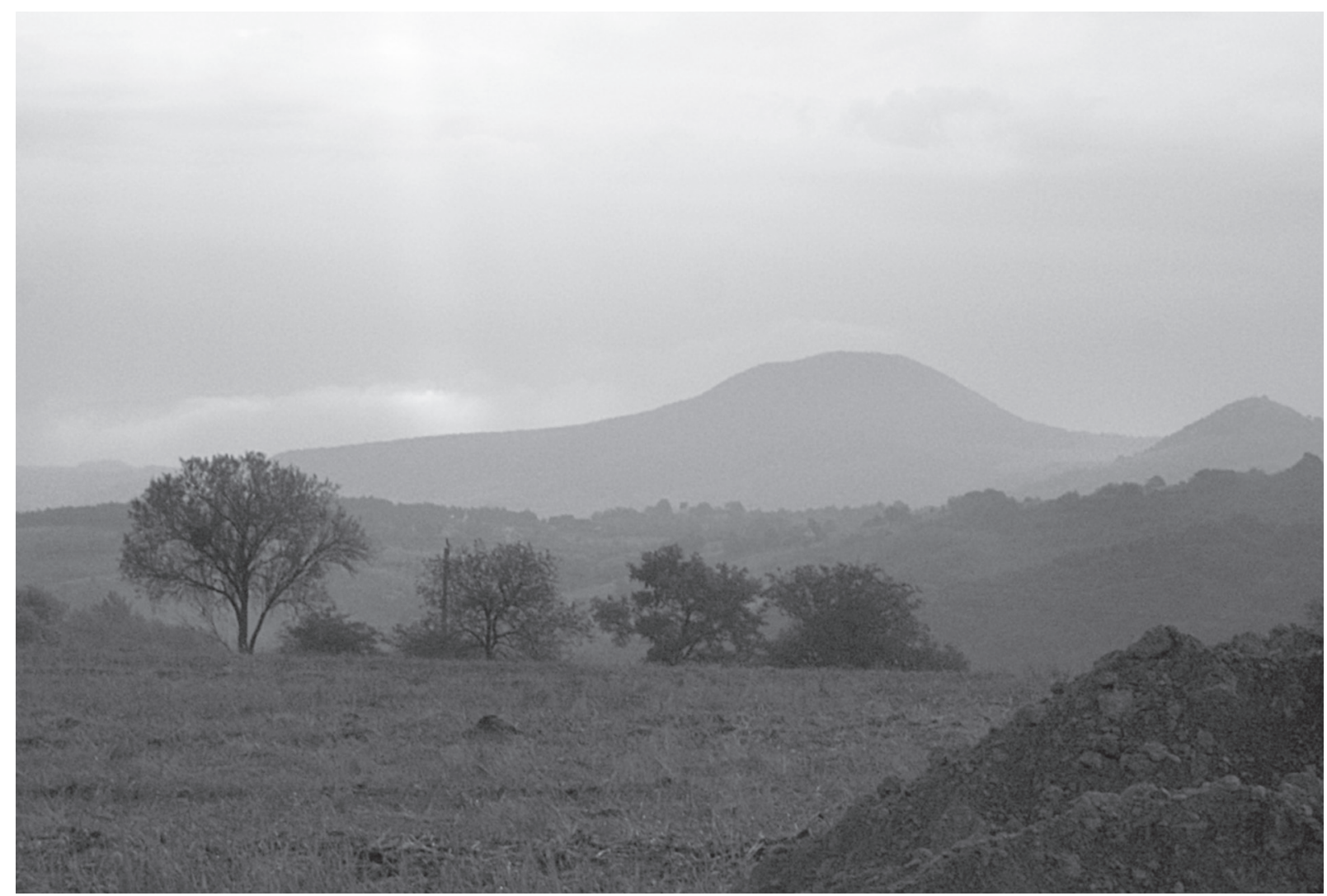

Fig. 3. Gete hill in the mist

\section{Tool kit (Fig. 5)}

The Ságvárian culture was contemporary with the older level of the Epigravettian cultures, which can be considered as descendants of the Pavlovian. Living within the same, closed territory, they both had the same geographical and climatic endowments and raw material sources. The Ságvárian population used, apart from the 'modern' technology of the age generally known and used in this period, a more archaic way of tool production.

Apart from pebbles, various raw materials were equally used. As much as we can judge from an uncorticated tool of 3-4 cm overall size, people also used blocks, tabular rocks in a thickness of $2-8 \mathrm{~cm}$ and large lumps. ${ }^{70}$ Tabular raw material could be collected e.g. from radiolarite layers of the Gerecse Mts. or regional raw material sources of hydrothermal origin at the terrace margins. The most characteristic feature of the culture is obviously the prevailing use of pebble raw material. We do not exactly know the gravel beds where the raw material was collected from, but we know that the older gravel beds of a mixed composition were in fact available within short distances and in an unlimited quantity. The suitable size range for the tools was consciously selected. Slicing egg-size pebbles is less economical as it will yield a lot of debris. The advantage of blade technique with properly prepared blade cores is obvious: it was more productive as it can be used further for the serial production of blanks while the waste detached from the pebbles will be typically discarded. In the Ságvárian culture industries, the ratio of cortical pieces and archaic geometrical forms is typically high.

The overall image of the Ságvárian lithic industry, its technical level and size range are equally the consequences of the selected raw material, i.e. the pebbles. Or, looking at this from the other side, the demands for tool-making, traditions and handicraft were best suited for the use of pebble raw material. 
MOGYORÓSBÁNYA UJFALUSI DOMBOK "ß"

2001. 07. 15.

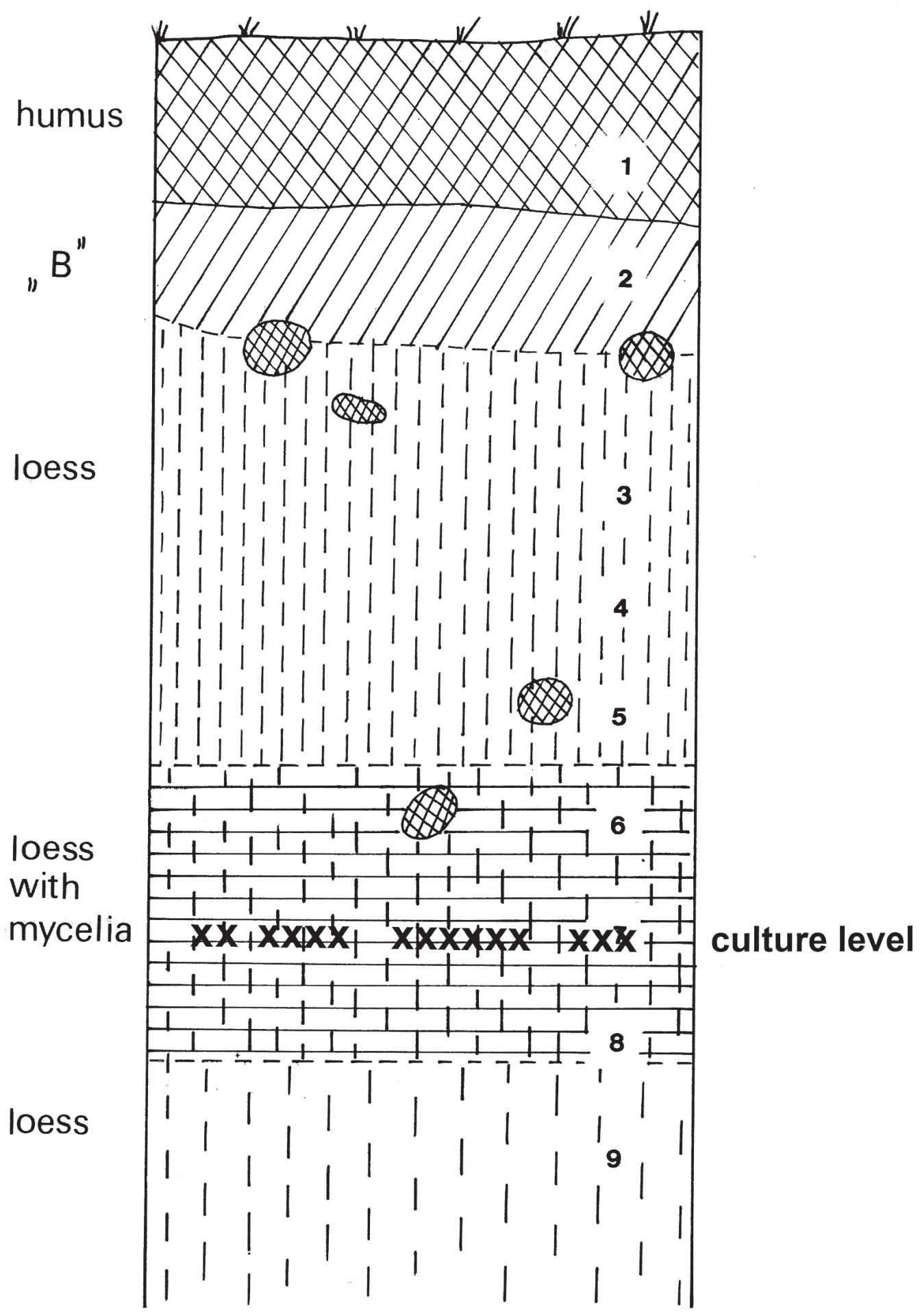

Fig. 4. Stratigraphy of the site, 1:10 

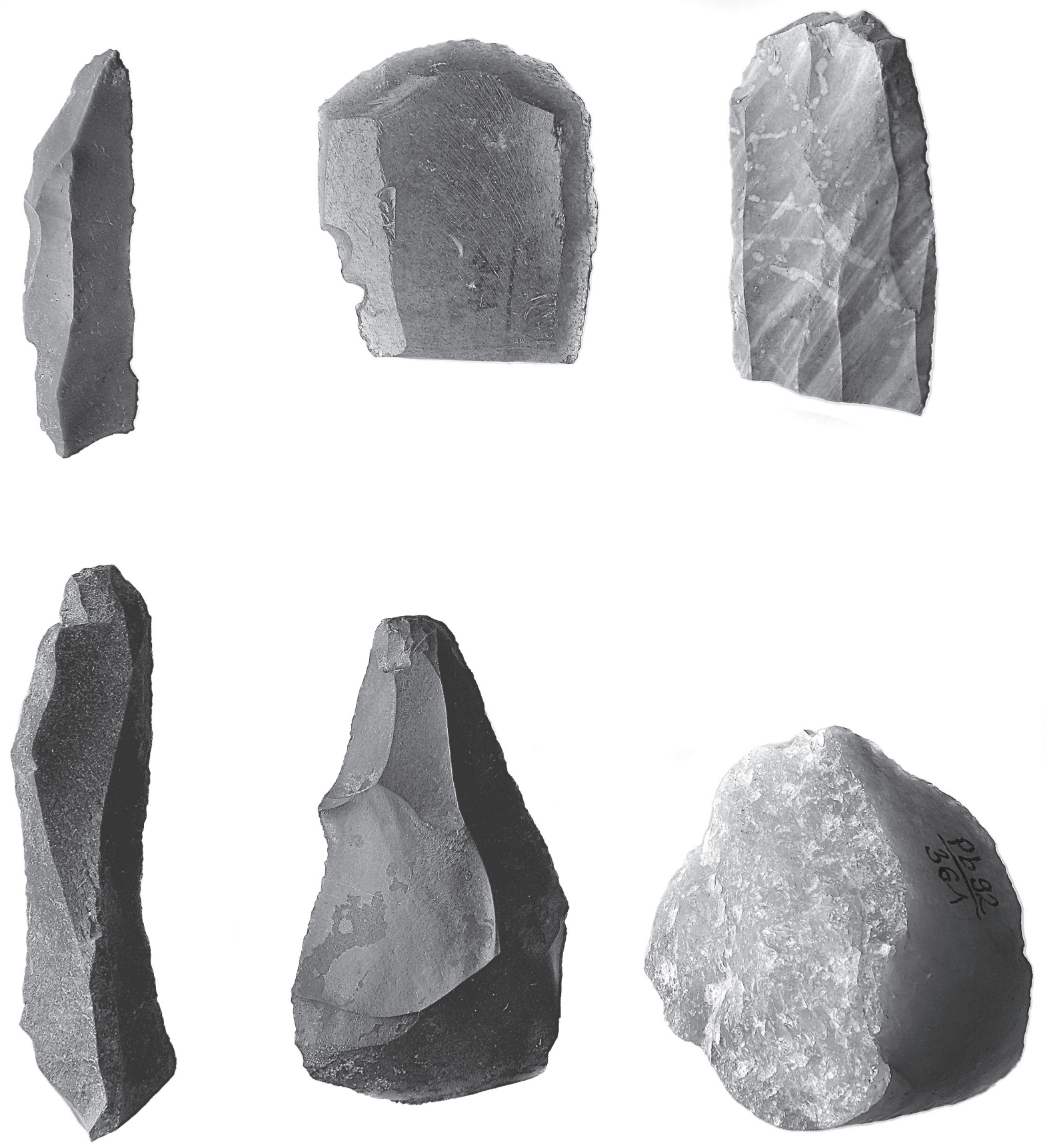

Fig. 5. Tools of mixed raw material (photo by J. Kardos) 
At Mogyorósbánya, the archaeological material collected from an approximately $350 \mathrm{~m}^{2}$ large settlement surface comprised 1913 items (7704). Among the finds, 7598 pieces were made of lithic raw materials. The archaeological and the faunistic material are stored in the Hungarian National Museum.

The type distribution is presented here, at the current state of research:

\begin{tabular}{|l|c|}
\hline \multicolumn{1}{|c|}{ Tools: } & $\%$ \\
\hline End-scraper and its combinations & 19 \\
\hline Burin and its combinations & 30 \\
\hline Point (Gravette-points, blade- and atypical shouldered points) & 3 \\
\hline Combined tool & 1.6 \\
\hline Truncated tool & 3.6 \\
\hline Backed (blunted) tool and blade & 2.5 \\
\hline Borer & 1.2 \\
\hline Chisel (shovel-form and nosed forms) & 9.5 \\
\hline Hafted tools & 1 \\
\hline Hand-axe & \\
\hline Side-scraper & \\
\hline Notched tools & \\
\hline Retouched blade & \\
\hline Retouched flake & \\
\hline
\end{tabular}

\begin{tabular}{|l|l|}
\hline Tools total & $\mathbf{5 4 7}$ pieces, $\mathbf{7 . 2 \%}$ percent of total \\
\hline Cores and core remnants & $\mathbf{1 7 6}$ pieces, $\mathbf{2 , 3 \%}$ percent of total \\
\hline Pebble derivates & $\mathbf{2 4 4}$ pieces, 3,2\% percent of total \\
\hline Pebble tools & 7 pieces \\
\hline Chopper chopping-tool & 27 pieces \\
\hline Segment & 161 pieces \\
\hline Slice & 10 pieces \\
\hline quartered pebble and geometrical fragment & 39 pieces \\
\hline Unretouched blade & $\mathbf{4 3 2}$ pieces, $\mathbf{5 . 7 \%}$ percent of total \\
\hline Flake, fabrication debris, fragment & $\mathbf{6 2 6 1}$ pieces, $\mathbf{8 2 . 4 \%}$ percent of total \\
\hline
\end{tabular}

Length distribution of the endscraper-burin-side scraper group

\begin{tabular}{|l|r|}
\hline \multicolumn{1}{|c|}{ Length groups: $\mathbf{m m}$} & $\%$ \\
\hline $10-19$ & $\mathbf{8}$ \\
\hline $20-29$ & 37 \\
\hline $30-39$ & 37.6 \\
\hline $40-49$ & 9.8 \\
\hline $50-59$ & 5.6 \\
\hline $60-69$ & 0.05 \\
\hline $70-79$ & 1 \\
\hline
\end{tabular}

\section{Average length: $32.3 \mathrm{~mm}$}




\section{Length-width ratio:}

Group I.: $1-1.5=$ width is between $100-66 \%$ of the length of the artefact Group II.: $1.5-2=$ width is between $66-50 \%$ of the length of the artefact Group III. : $2-3=$ width is between $50-33 \%$ of the length of the artefact Group IV.: $3-4=$ width is between $33-25 \%$ of the length of the artefact Group V.: 4-5 = width is between $25-20 \%$ of the length of the artefact Group VI.: 5-6 = width is between $20-16 \%$ of the length of the artefact

\begin{tabular}{|c|c|c|c|c|c|}
\hline group & $\begin{array}{c}\text { Blade } \\
\text { (pieces) }\end{array}$ & Burin (pieces) & End-scraper (pieces) & Total (pieces) & \% \\
\hline I. & 27 & 78 & 26 & $\mathbf{1 3 1}$ & $\mathbf{2 2 . 5}$ \\
\hline II & 73 & 55 & 20 & $\mathbf{1 4 8}$ & $\mathbf{2 5 . 4}$ \\
\hline III & 153 & 27 & 10 & $\mathbf{1 9 0}$ & $\mathbf{3 2 . 6}$ \\
\hline IV & 71 & 7 & 2 & $\mathbf{8 0}$ & $\mathbf{1 3 . 7}$ \\
\hline V & 24 & 1 & 1 & $\mathbf{2 5}$ & $\mathbf{4}$ \\
\hline VI & 8 & & & & $\mathbf{0 . 0 2}$ \\
\hline
\end{tabular}

The width of the measured artefacts is only $49 \%$ of the length, surpassing the dimensional criteria of blades only by $1 \%$ (length should be minimum two times the width). Burins (133 pieces, $80 \%$ ) and end-scrapers (46 pieces, $78 \%$ ) basically belong into groups I-II while $63 \%$ of the blades (224 pieces) belong to groups III-IV.

The tools within the lithic assemblage of Mogyorósbánya are typically short, bulky, with weak laminarisation.

The ratio of end-scrapers (Fig. 6) is about 25\%; within this number, the ratio of blade vs. flake scrapers and high scrapers (rabots) is approximately equal. High scrapers/rabots represent the (pseudo)-Aurignacian reminiscences. The traditional task of a rabot, however, can hardly be accomplished using a $3-4 \mathrm{~cm}$ large tool clamped between two fingers.

The number of burins surpassed the end-scrapers as it is typical for the Gravettian phyla. Their ratio among the tools is approximately $40 \%$. Most of them are medial burins, followed by lateral burins and double burins. The burin edge is often combined with truncation. The ratio of retouched and truncated blades is not outstanding. Typical Gravette-points are surprisingly rare. Backed microblades (Figs 7-8) are equally typical for the Ságvárian and the coeval industries of the older phase of Epigravettian.

Due to the small size of the artefacts in the assemblage, the blades are mainly atypical.

Some pebble cortex was preserved on many of the tools and the cores, and this is the reason for separating the industry as 'pebble-Gravettian'.

The constituents of the pebble section in the Mogyorósbánya assemblage are as follows:

Standard groups are chopping-tool and chopper, this latter often mistaken for a core. The flake detached by a chopper-retouch, however, is not suitable for further processing. Moreover, cores can clearly be separated in the Ságvárian industry as well as clove scrapers which are the dominant tool types in any pebble industries The non-standard group is comprised of unworked (citrus) cloves, natural backed blades, slices, with slightly curved cortex on the external side, geometrically broken half- and quartered pebbles with a diamond-shaped cross-section. The tools were locally produced, the ratio of flakes and fabrication debris is $82 \%$. 

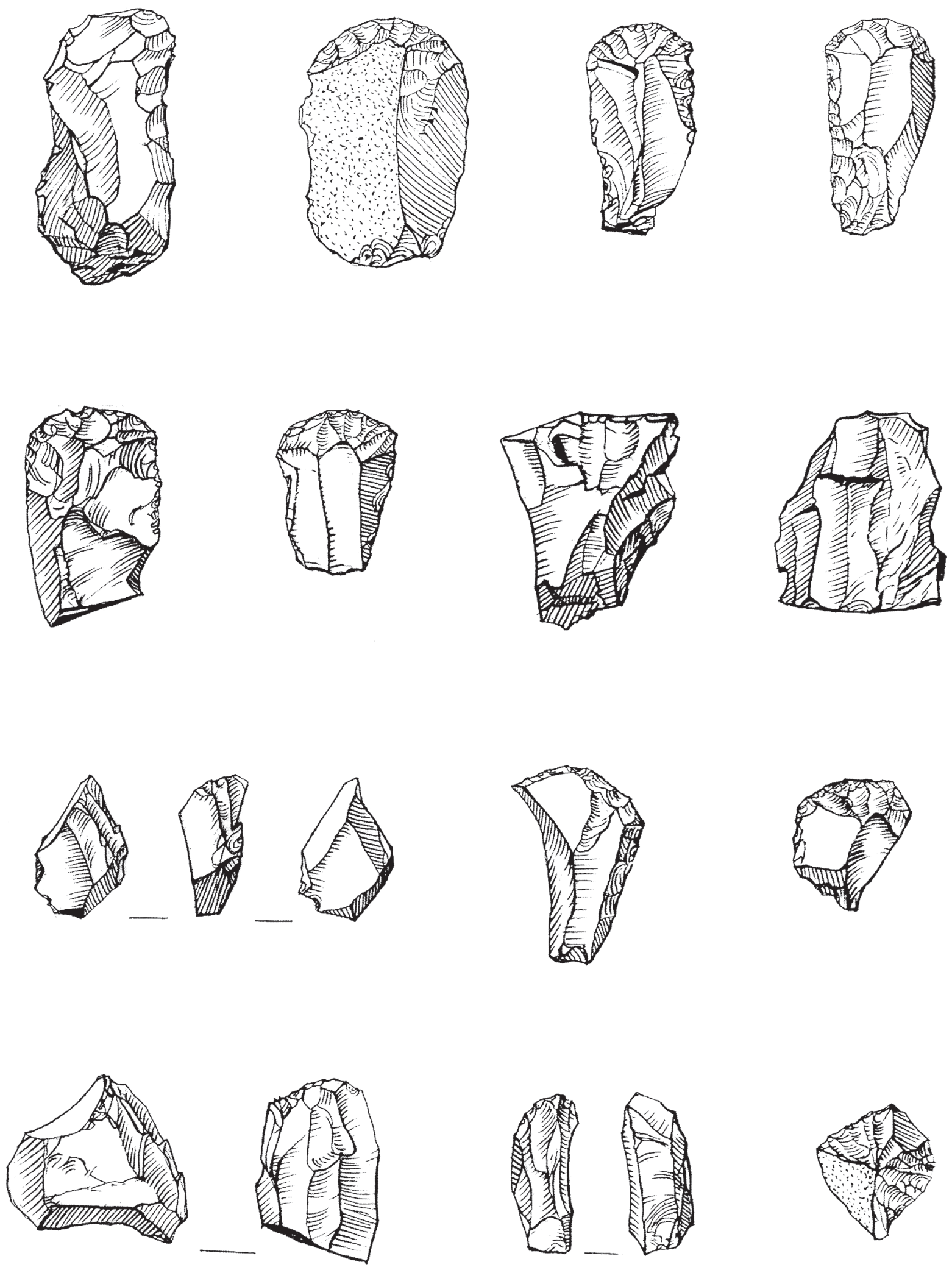

Fig. 6. Endscrapers (drawing by K. Nagy) 


\section{Raw material}

In his paper, Gy. Lengyel argued concerning the accessibility of raw materials from outside the Carpathian Basin that raw material acquisition and consequently, cultural connections depend on climate. For the first phase of the LGM (claimed between 24-17 kyear BP) he supposed contracting acquisition possibilities and lesser mobility, changing favourably in the next 3000 years. ${ }^{71}$ The revival of the contacts is shown by the appearance of distant raw materials exemplified by the sites Jászfelsőszentgyörgy-Szúnyogos and -Székes dülö. According to traditional (18500 4 400) and calibrated data (20 590-19450), they are LGM sites themselves belonging to the older phase of the Epigravettian culture, contemporary to the Ságvárian culture. In the tool kit, almost all of the raw materials from outside the Carpathian Basin that generally occur in the Palaeolithic are represented, namely Prut flint, erratic flint, Jurassic Cracow flint, Chocolate flint and rock crystal. ${ }^{72}$
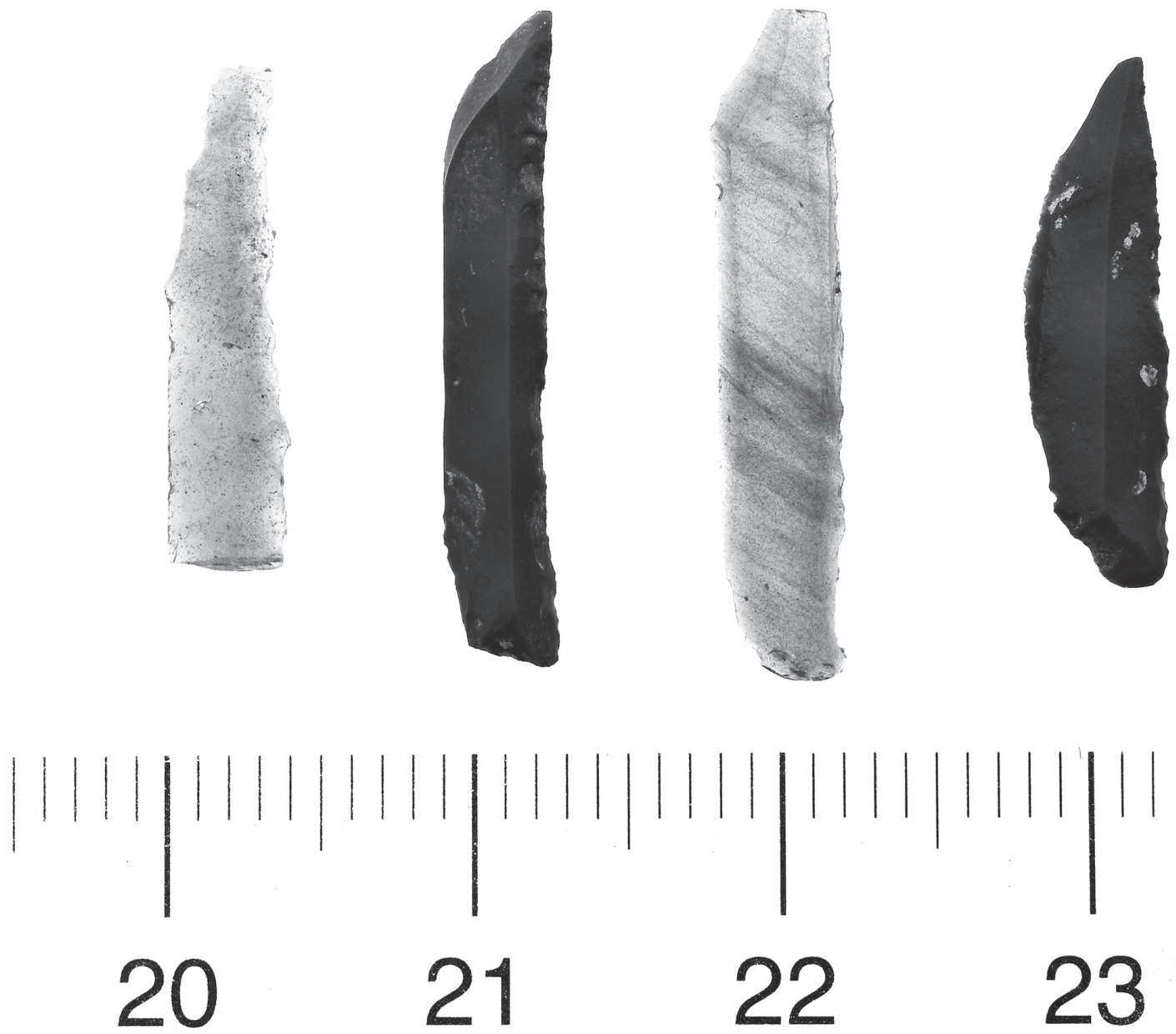

Fig. 7. Microlithic blades (photo by J. Kardos) 

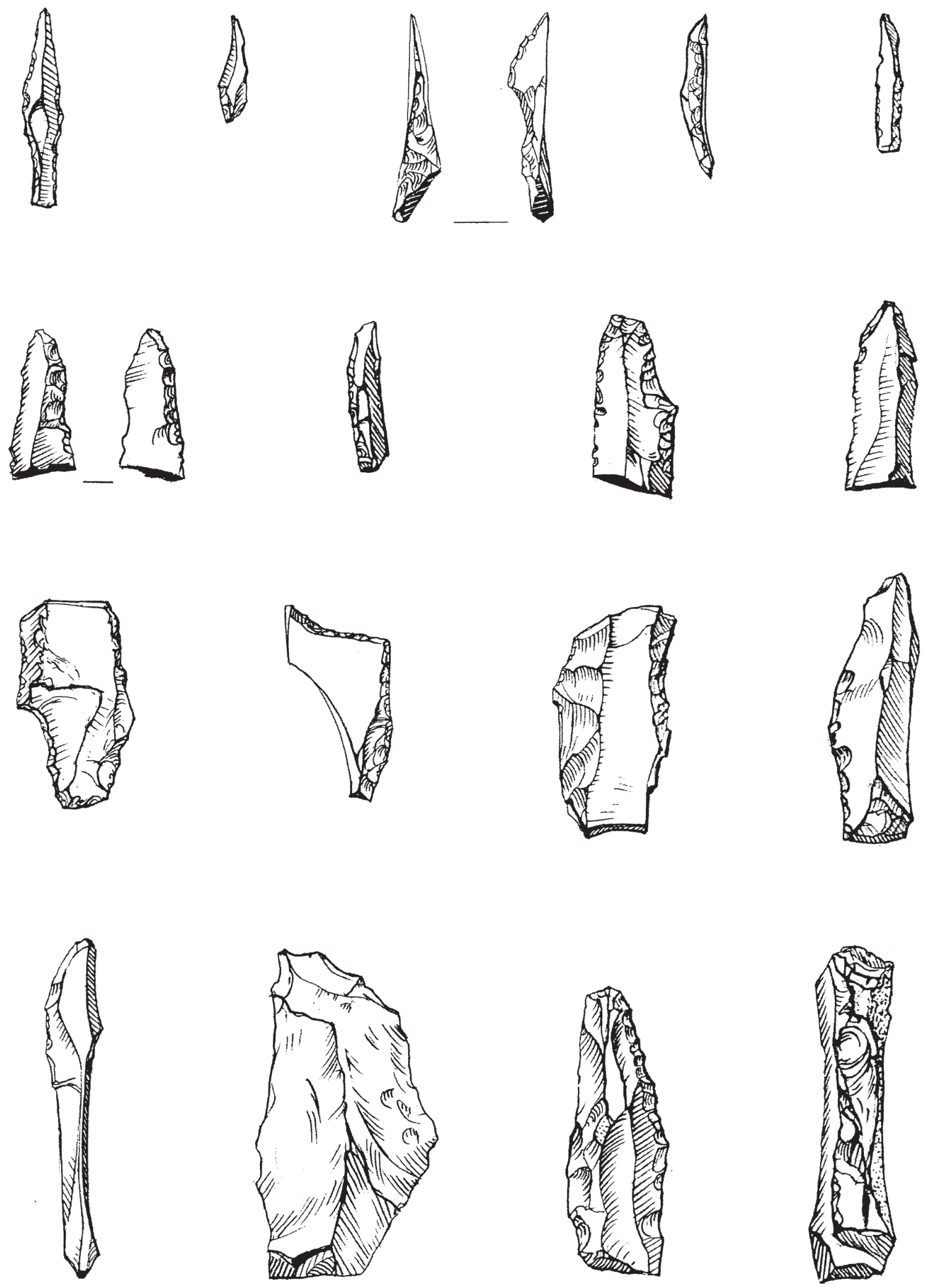

Fig. 8. Retouched blades and flakes (drawing by K. Nagy) 
Raw material utilisation at Mogyorósbánya

\begin{tabular}{|l|c|}
\hline \multicolumn{1}{|c|}{ Raw material } & $\%$ \\
\hline Silex & 73 \\
\hline Erratic flint & 6 \\
\hline Radiolarite & 6 \\
\hline hornstone & + \\
\hline Obsidian & 5 \\
\hline Hydro/limnoquartzite & 3 \\
\hline quartzite & 7 \\
\hline rock crystal & + \\
\hline Other Mesozoic rocks & + \\
\hline
\end{tabular}

The formerly known raw material sources were mainly known and used. So far, the Szeletian felsitic porphyry/metarhyolite is missing from the list.

Classical long-distance raw materials found at Mogyorósbánya include the followings:

Silesian erratic flint

Prut flint: one of the possible routes for the appearance of the raw material could be the Maros (Mureş) valley. Szeged-Öthalom, facing the mouth of the Maros river could be a post on the route

Jurassic Cracow flint reached as far as Ságvár ${ }^{73}$

Rock crystal was known both in the older blade industries of the Gravettian and the Epigravettian settlements. The likely sources are located on the Eastern Alpine territories, $400 \mathrm{~km}$ to the west as the crow flies.

At Mogyorósbánya, the Gerecse radiolarite can be considered as the local raw material. The ratio of obsidian is remarkable. It can be obtained from secondary sources as nut/egg size lumps, very similar to rounded pebbles. Its quality is exceptionally good, The possible origin is the Tokaj-Prešov mountains, the exact sources will be investigated by further studies.

Hydrothermal raw materials and quartzite can be obtained from terrace pebbles and river sediments.

Exotic objects Fragments of coral and Ammonites found at Mogyorósbánya can be collected on the surface of the Mesozoic limestone sequences of the Gerecse Mts. Nummulites (popularly called St. Laszlo's coins) was also found on the settlement; it can be collected on the other side of the valley from younger limestone sediments. Fragments of phyllite, unfit for the production of stone tools, was also found at Mogyorósbánya; its geological occurrence, however, is not known in the neighbourhood.

Ornate shell: Tertiary snails ('trinket snails') tend to occur at almost all of the Upper Palaeolithic sites, independent of cultural affiliation, especially in the Danube Bend region. At Mogyorósbánya, 85 pieces were found. (Fig. 9) The trinket snails found at the neighbouring Esztergom-Gyurgyalag site were collected, according to the malacological analysis, at least from two distinct localities of different geological ages and biofacies from the Baden (Miocene) and the Oligocene periods at nearby localities on the right bank of the Danube ${ }^{74}$ or the $^{-}$ Middle Miocene layers wedging along the Western margin of the Börzsöny Mts., like in the case of the SzobIpolypart trinket snail depot find. ${ }^{75}$ The sources could probably be the same for Mogyorósbánya. Traces of shell elaboration are rare on the settlements: the shells are not pierced. On Dentalia, the narrowing ends of the shell are often cut off.

In the same chronological level of the Upper Palaeolithic when trinket snails proliferate, we also find significant quantities of ochre, namely in the 18-19 BP kyear old Ságvárian and the 18-16 BP kyear old Epigravettian settlements. It means that the need for commodities that do no directly serve subsistence grew, placing more emphasis on aesthetic appearance and a pleasant environment and suggesting that people had enough time to obtain such goods.

Mogyorósbánya is the 'reddest' from all the known Upper Palaeolithic sites in Hungary. We have found several large lumps of ochre (Fig. 10), the cultural layer was stained on large surfaces by soaked ochre. According

\footnotetext{
${ }^{73}$ LENGYEL 2011, 95.

${ }^{74}$ MAGYAR 1991, 266
}

${ }^{75}$ MARKÓ 2007. 


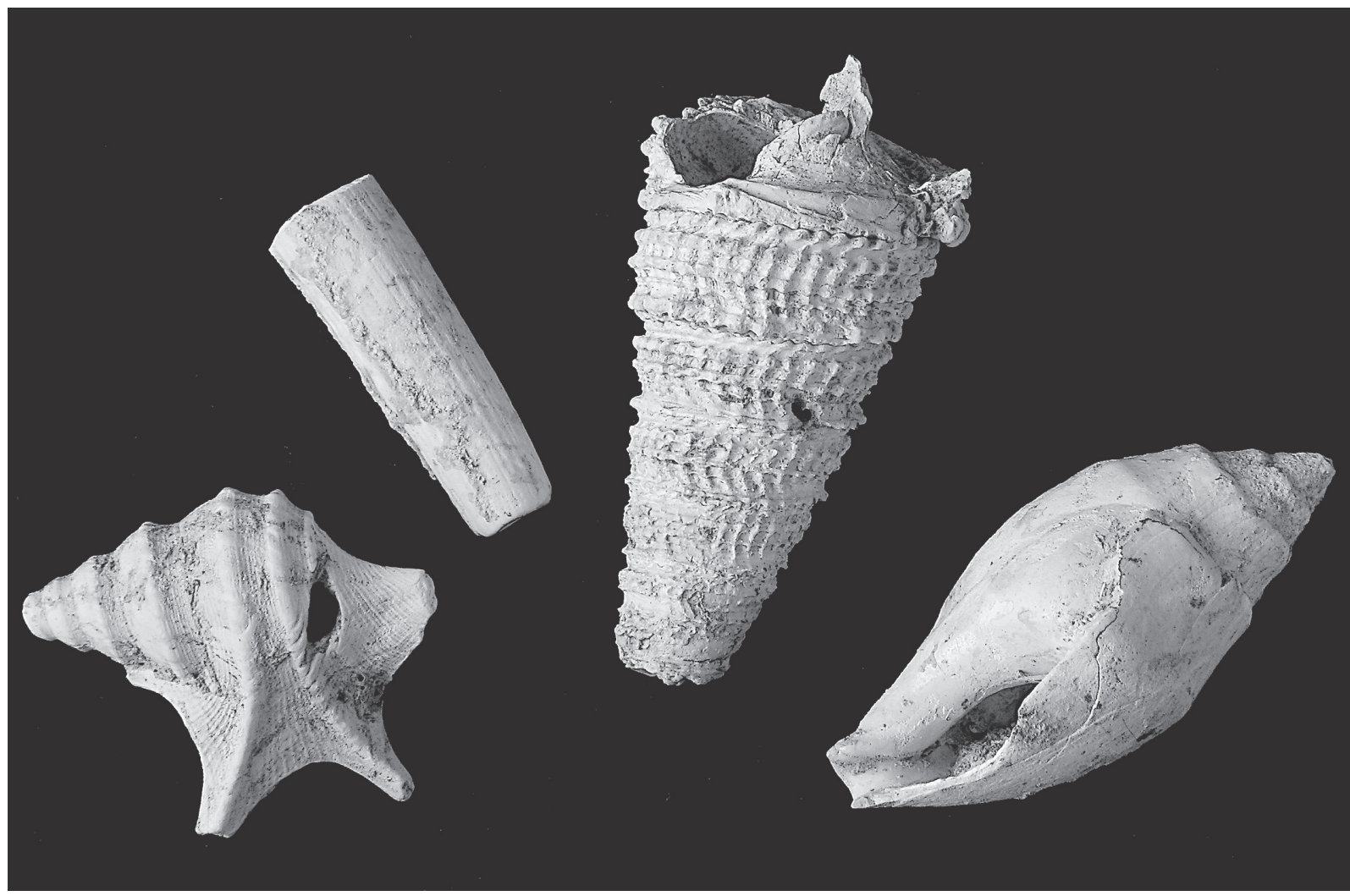

Fig. 9. Miocene snail shells from cultural layer (photo by A. Dabasi)

to mineralogical analysis, the pigment contained variable quantities of iron oxide and alumino-silicates, some samples also contained quartz and relatively little carbonate (calcite). ${ }^{76}$

There was a single piece of amber found on the site. Its origin was investigated by infra-red spectroscopy, but no finite opinion could be formulated on its provenance. ${ }^{77}$

\section{HUNGARIAN SETTLEMENTS OF THE SÁGVÁRIAN CULTURE}

The eponymous site of the Ságvárian culture is Ságvár-Lyukasdomb, known since 1909. It is located in the loess region flanking the lake Balaton from the south, in the valley of the Jaba stream. The differences of the character of the archaeological assemblage as compared to the settlements discovered a somewhat later in the Danube Bend region were soon recognised. Several theories were conceived to explain the duality in the younger phases of the Hungarian Upper Palaeolithic (described, according to the actual terminology, Loess Magdalénian-Late Aurignacian-Eastern Gravettian). The currently accepted concept was accepted in several steps. First, the Lascaux-Ságvár interstadial phase was established, which was a significant advance in synchronising Late Pleistocene loess stratigraphy with the archaeological periodisation. The recognition of further sites similar to Ságvár confirmed that apart from the Late Palaeolithic groups with blade tradition, a coeval group of population preferring pebble raw material also inhabited the Carpathian Basin.

The latest publication of Ságvár is about the raw material use written by Gy. Lengyel.

The sources were in the Transdanubian mid-mountain area, east of of the Danube, in the Prut and the Krakow Jurassic area and beside rocks of limnic origin from unknow sources. The percentage of debris made of pebble is $32.8 \%$ (918 pieces among 2792), that of tools made of pebble is $35 \%$ (105 pieces among 309 ). ${ }^{78}$

\footnotetext{
${ }^{76}$ MiHÁLy 2011, 554.

${ }^{77}$ FÖLDVÁRI 1991, 17.
} 


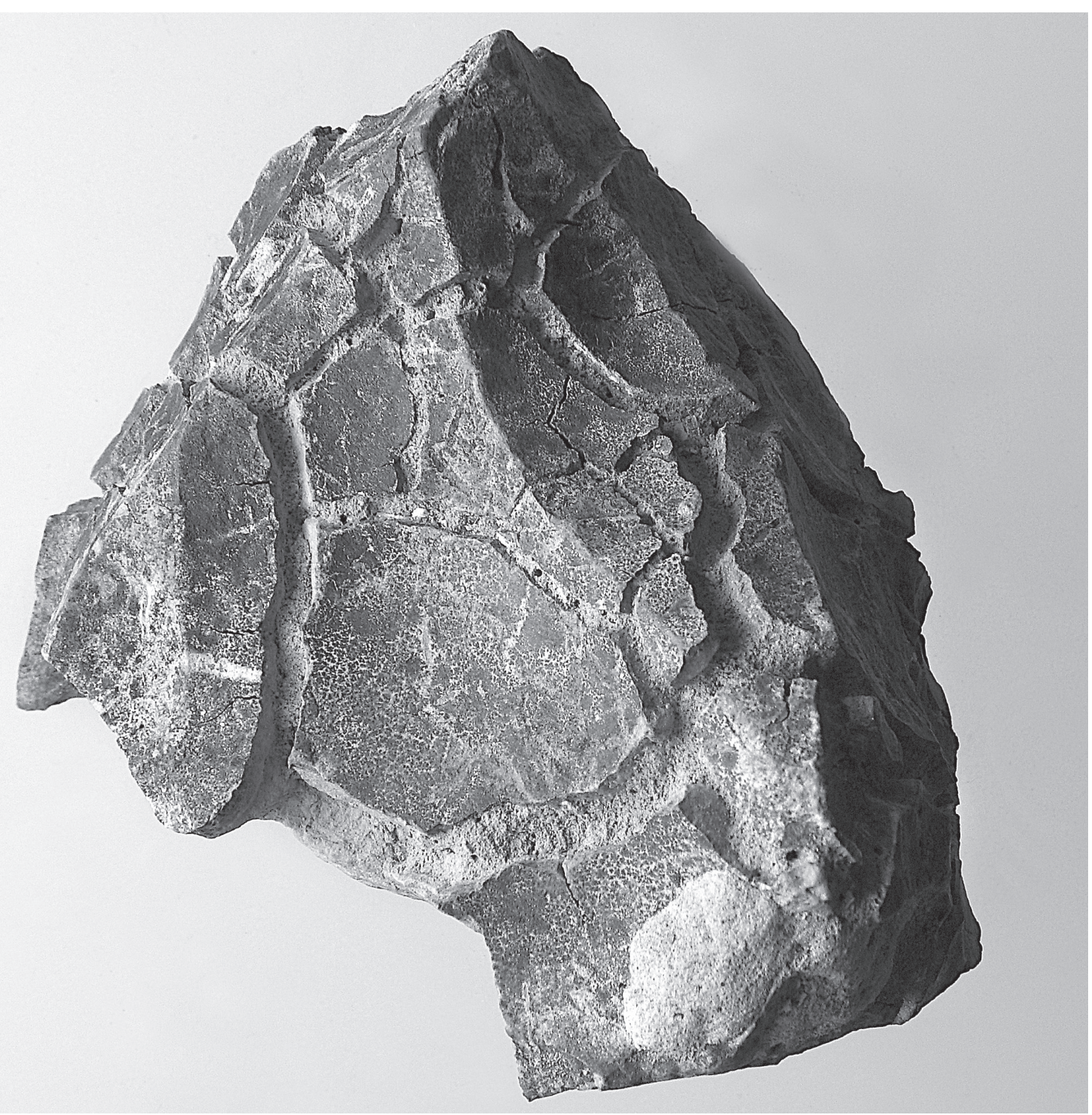

Fig. 10. Ochre lump (photo by J. Kardos)

The length groups are as follows (dimensions are in CsONGRÁDINÉ BALOGH 200079):

\begin{tabular}{|l|c|c|c|c|c|c|}
\hline $\begin{array}{c}\text { Length groups: } \\
\text { mm }\end{array}$ & $\begin{array}{c}\text { Lower Layer } \\
\text { Item no. }\end{array}$ & $\begin{array}{c}\text { Upper Layer } \\
\text { Item no. }\end{array}$ & $\begin{array}{c}\text { Unidentificated } \\
\text { Layer } \\
\text { Item no. }\end{array}$ & $\begin{array}{c}\text { Total } \\
\text { Item no. }\end{array}$ & $\begin{array}{c}\text { Ságvár } \\
\mathbf{\%}\end{array}$ & $\begin{array}{c}\text { Mogyorósbánya } \\
\text { \% }\end{array}$ \\
\hline $10-19$ & 5 & 26 & 44 & $\mathbf{7 5}$ & $\mathbf{8 . 8}$ & $\mathbf{8}$ \\
\hline $20-29$ & 30 & 119 & 170 & $\mathbf{3 1 9}$ & $\mathbf{3 7 . 7}$ & $\mathbf{3 7}$ \\
\hline $30-39$ & 33 & 101 & 141 & $\mathbf{2 7 5}$ & $\mathbf{3 2 . 6}$ & $\mathbf{3 7 . 6}$ \\
\hline $40-49$ & 15 & 49 & 41 & $\mathbf{1 0 5}$ & $\mathbf{1 2 . 4}$ & $\mathbf{9 . 8}$ \\
\hline $60-59$ & 1 & 17 & 33 & $\mathbf{5 1}$ & $\mathbf{6 . 0}$ & $\mathbf{5 . 6}$ \\
\hline $70-79$ & 1 & 5 & 14 & $\mathbf{2 0}$ & $\mathbf{2 . 3}$ & $\mathbf{0 . 0 5}$ \\
\hline Sum & & 1 & & $\mathbf{1}$ & + & \\
\hline
\end{tabular}

Average of length: Ságvár 32.7, Mogyorósbánya 32.3

\footnotetext{
${ }^{79}$ Csongrádiné BALOGH 2000, 4-20.
} 
The need for authenticating the site Ságvár-Lyukasdomb by modern methods became topical when Gy. Lengyel started to deny the existence of the two cultural layers, which were cited as evidence since the first publication. ${ }^{80}$

Madaras-Téglavetö: Several burned patches, bone fragment and silex flakes were found during clay exploitation for bricks on the northern margin of the Telecska hills, along the Kígyós stream, which is currently running in a regulated bed. During the excavations, hearths of a dieameter of 150-180 cm and ring-like structure were unearthed, implemental probably in drying preservation of meat. The fauna were Equus and Avis (eggshells, probably Lagopus).The archaeological material contained 280 worked pieces, among them 18 typical tools. The Madaras settlement was located $680-720 \mathrm{~cm}$ below the current surface. ${ }^{81}$ The covering loess layer is essentially thicker than at most of the contemporary sites. At the also contemporary eponymous site of Ságvár, there is 1 meter sterile loess in between the two embryonal soil layers dated by radiometric chronological method, indicating, in a rough estimation, loess accumulation of 1 meter/thousand year. We have no reason to suppose essential differences in the climate within the Carpathian Basin that would explain widely different paces of sedimentation in the formation of the loess cover. That is, the orographical factors must have had a decisive role in the sedimentation, and also in the erosion of the loess at various localities. No general rules can be applied in this respect.

Szob-Ipoly-part. The alluvial plain of the Ipoly river is connected to the ice-age terraces by a slight, southwards exposed alluvial plain at the mouth of the Ipoly river as it reaches the Danube in the middle of the Danube Bend. On the youngest terrace, a large but not very intensive Palaeolithic settlement was found and excavated by several scholars. After M. Mottl, S. Gallus and Gy. Bacsák, Adolf János Horváth excavated the site from $1935^{82}$ and in 1965-1966, M. Gábori excavated several hundred square meters.

The detailed elaboration of the site was completed much later by András Markó. There were 74 typical tools, 70 blades, 13 cores, 27 pebble tools and 276 pieces of raw material fragments, flakes and fabrication debris found on the site. The large settlement of a low intensity had a hearth flanked with large stone slabs, indicating a longer habitation. The fauna comprised Rangifer, mammoth and Coelodonta. The site was destroyed. ${ }^{83}$

In 1997, small details of an Upper Palaeolithic settlement were excavated at Budapest-Corvin tér. The site was heavily disturbed by Late Medieval/Modern Age habitations. Among the 383 pieces of worked artefacts, only 12 can be regarded as typical tools. The find assemblage was assigned to the Ságvárian. ${ }^{84}$

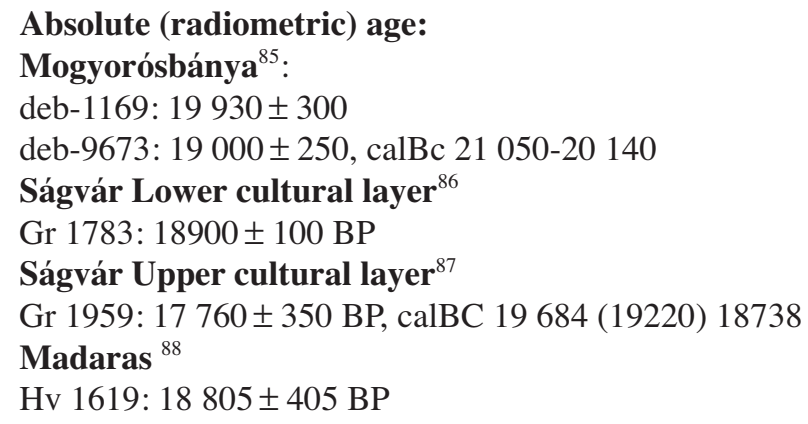

SUMMARY

By the accumulation of the sites and the relevant pieces of information, we can delineate the cultural features of the Middle and Late phases of the Upper Palaeolithic. The interior parts of the Carpathian Basin were populated in several waves (as attested to by transitional or permanent settlements) in course of regular hunting or expeditions for raw material by the surplus population of the cultural centres lying to the West and the Northwest.

\footnotetext{
${ }^{80}$ LENGYEL 2010, 34.

${ }^{81}$ DoBosi et al. 1989.

${ }^{82}$ GÁBORI-GÁBORI 1957, 48.

${ }^{83}$ MARKÓ 2007.

${ }^{84}$ Ringer-LENGYeL 2008-2009.
}

${ }^{85}$ Hertelendi 1992, 16.

${ }^{86}$ Dobosi-SZÁntó 2003, 11.

${ }^{87}$ Dobosi-SzÁntó 2003, 11.

${ }^{88}$ Dobosi-SzÁNTó 2003, 11. 
The so-called Gravettian entity, which is basically uniform in its ecological demands, way of life and cultural goods, can be divided into three chronological-typological levels:

- group of sites connected to the Pavlovian circle: dated to 28-26 kyear BP, main sites: Bodrogkeresztúr, Hont, Megyaszó. At the latter site, two cultural layers were discovered in immediate superposition at the depth of 50-60 am and 80-90 cm, respectively, with identical archaeological materials.

- 'Pebble Gravettian' or Ságvárian culture dated to 20-18 kyear BP, the eponymous site is Ságvár, stratotype Mogyorósbánya, the former one with two, the latter with a single level of habitation.

- The Epigravettian in our concept is not only a chronological entity ${ }^{89}$ but also the descendant of the Pavlovian culture. This unit can be further divided into two levels. The older one is partly contemporary with the Ságvárian: 18-16 kyear BP, partly present in scattered traces on top of the loess at the end of the Ice Age: Pilismarót-Bánom, Jászság.

The intensive eastern migration of the Magdalénian expansion did not reach, according to our present state of knowledge, the Carpathian Basin but circumvented it from the North..$^{90}$

Gy. Lengyel recently made a proposition for a new archaeological division of the Gravettian period. ${ }^{91}$ The basic idea that the Hungarian Late and Middle Upper Palaeolithic sites should conform better to the Central European system is not new and obviously well founded. The absence of the marker tool types in Hungary, the low number of sites and the scarcity and incidental character of the finds, the difficulties in properly interpreting the stratigraphical relations of old sites, however, urges caution. The confirmation of the new theories can be expected from new evidences, new sites.

Ságvárian culture, as we can see so far, lived in a relatively short period and extended over the complete interior region of the Carpathian Basin. Compared to contemporary local Epipalaeolithic sites, the settlements are large and inhabited for longer periods, even though we have not yet found a classical 'base camp'. At Ságvár, partly subterranean living huts, at Madaras, several ring-shaped large hearths probably for meat preservation. At Szob, stone-encircled hearths and trinket snail depots were found. At Mogyorósbánya, there were three habitation surfaces separated by sterile stripes.

The overall image of the Ságvárian industry, the type spectrum, the technical level and size range are all in close relation with the preferred raw material, i.e. pebbles. The demands and traditions as well as the manual skills were all best suited to this form of raw material. Within the tool kit, the ratio of pebble sections is high, apart from non-standard types (segments, slices, geometrically broken pebbles: ad-hoc tools) and there are choppers and chopping-tools as well as side scrapers on segment in the industry.

The ratio of morphological tools within the assemblage is $7.2 \%$. End-scrapers comprise $19 \%$ within the tools while burins constitute $30 \%$ among the tools proper.

The average size of the artefacts is $32.3 \mathrm{~mm}$ at Mogyorósbánya and at $28.7 \mathrm{~mm}$ at Ságvár.

Laminarisation is low, the width/length ratio only slightly surpasses 1:2.

Sites in Hungary are Ságvár, Mogyorósbánya, Madaras, Szob and Budapest-Corvin square.

\section{REFERENCES}

BÁNESZ et al. 1992

BRADÁK et al. 2013

BRANDTNER 1996

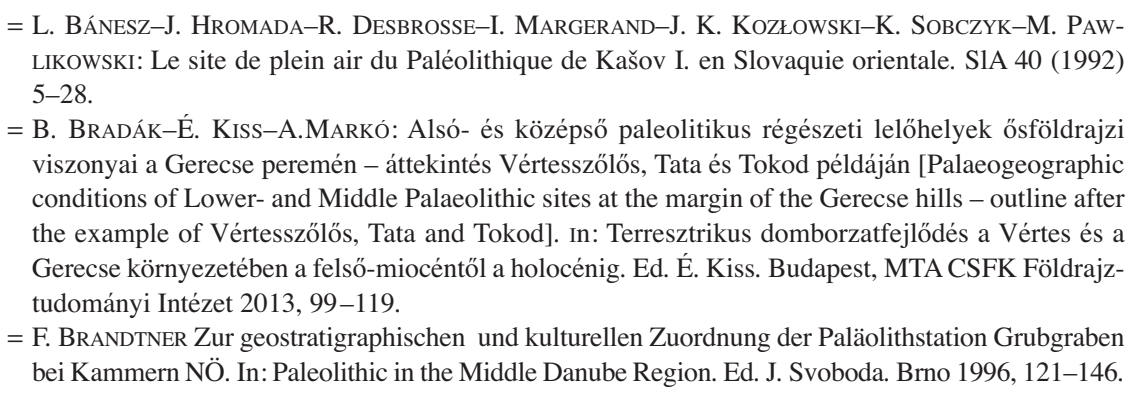

= L. BÁnesZ-J. Hromada-R. Desbrosse-I. Margerand-J. K. KozŁowski-K. SobczyK-M. PawLIKOwSKI: Le site de plein air du Paléolithique de Kašov I. en Slovaquie orientale. SlA 40 (1992) $5-28$.

= B. BRADÁK-É. KISS-A.MARKó: Alsó- és középső paleolitikus régészeti lelöhelyek ősföldrajzi viszonyai a Gerecse peremén - áttekintés Vértesszőlős, Tata és Tokod példáján [Palaeogeographic conditions of Lower- and Middle Palaeolithic sites at the margin of the Gerecse hills - outline after the example of Vértesszőlős, Tata and Tokod]. In: Terresztrikus domborzatfejlödés a Vértes és a Gerecse környezetében a felső-miocéntől a holocénig. Ed. É. Kiss. Budapest, MTA CSFK Földrajztudományi Intézet 2013, 99-119.

= F. BRANDTNER Zur geostratigraphischen und kulturellen Zuordnung der Paläolithstation Grubgraben bei Kammern NÖ. In: Paleolithic in the Middle Danube Region. Ed. J. Svoboda. Brno 1996, 121-146.

\footnotetext{
${ }^{89}$ Svoboda 2004a, 289.

${ }^{90}$ KozŁowski et al. 2012, 295.
}

${ }^{91}$ LeNGYel 2014.

Acta Archaeologica Academiae Scientiarum Hungaricae 67, 2016 
Cherdintsev-KaZachevski 1990

CsOngrádiné BALOGH 2000

DIENES 1968

DJINDJIAN, et al. 1999

DoBosi 1986

Dobosi 1990a

Dobosi 1990b

DoBosi 1993

DoBosi 1997

DoBosi 1998-1999

DoBosi 2000

Dobosi 2001

DoBosi 2006

DoBosi 2007

Doвosi et al. 1989

DoBosi-SzÁNTÓ 2003

FÖLDVÁRI 1992

GAMBLE 1986

GÁBORI 1969

GÁBORI- GÁBORI 1957

GÁBORI-CsÁNK 1978

GÁBORI-CSÁNK 1983.

HAHN et al. 2002

HENNIG et al.1983

HERTELENDI 1992

JÁNOSSY 1990

JÁRAI-KOMLÓDI 2000

KAMINSKA 2000

KAMINSKA-TOMÁŠOVÁ 2004
= V. V. Cherdintsev-I. V. Kazachevski: Absolute date of the travertine samples. In: Vértesszőlős, man, site and culture. Eds: M. Kretzoi, V. T. Dobosi. Budapest, Akadémiai Kiadó 1990, 547.

= É. CSONGRÁDINÉ BALOGH: A ságvári késői felsőpaleolit lelőhelyről és környékéről előkerült leletanyag ismertetése [A survey of the finds came to light from the Late Upper Palaeolithic Ságvár site and its neighbourhood]. SMK 14 (2000) 3-28.

= I. DiEnES: Examen petrographique de l'industrie. In: V. Gábori-Csánk: La station du paléolithique moyen d'Érd-Hongrie. Budapest 1968, 111-114.

= F. DJindjiAn-J. K. KozŁowsKI-M. OtTE: Le paléolithique supérieur en Europe. Paris, Armand Colin 1999.

= V. T. DoBosi: Historical sketch of the Late Palaeolithic in Hungary. In: The Pleistocene Perspective. 1. WAC. Southampton-London 1986.

= V. T. Dobosi: Description of the archaeological material. In: Vértesszőlős, Man, Site and Culture. Eds: M. Kretzoi, V. T. Dobosi. Budapest, Akadémiai Kiadó 1990, 311-396.

= L. VÉRTES-V. T. Dobosi: Fireplaces of the settlement. In: Vértesszőlős, Man, Site and Culture. Eds. : M. Kretzoi,V. T. Dobosi. Budapest, Akadémiai Kiadó 1990, 519-521.

= V. T. Dobosi: Jászfelsőszentgyörgy-Szúnyogos, Upper Palaeolithic locality. Tisicum 8 (1993) 41-60.

= V. T. Doвosi: Raw material management of the Upper Palaeolithic (a case study of five new sites, Hungary). In: Man and Flint. Proceedings of the VII ${ }^{\text {th }}$ International Flint Symposium. Eds: R. Shild, Z. Sulgostowska. Warszawa 1997, 189-193.

= V. T. Dobosi: Upper Palaeolithic open air sites. Settlement features and function. ArchA 82-83 (1998-1999) 57-63.

= V. T. Dobosi: Archaeological investigations at Bodogkeresztur-Henye. In: Bodrogkeresztur-Henye (Ne-Hungary), Upper Palaelithic site. Ed.: V. T. Dobosi. Budapest, Magyar Nemzeti Múzeum 2000, 5-111.

= V. TolnAI-DOBosi: About Ságvárian: chronological-cultural sketch of the Upper Palaeolithic in Hungary. In: Problems of the Old Stone Age in the Old World. Jubilee book dedicated to Professor Janusz K. Kozłowski. Cracow 2001, 195-201.

= V. T. Dobosı: Gravetti lelőhelyek Pilismarót környékén (Gravettian sites around Pilismarót). FolArch 52 (2006) 21-48.

= V. T. Dobosi: On the edges of the plains. In: Studies in the Final Paleolithic Settlement of the Great European Plain. Eds: M. Kobusiewicz, M. Kabacinski. Poznan 2007, 151-155.

= V. T. Dobosi-M. KöHegYI-E. Krolopp-I. Vörös-K. Biró: Felső-paleolit telep MadarasTéglavetőben (Jungpaläolithische Siedlung in Madaras-Téglavető). Cumania 11 (1989) 9-66.

= V. T. DoBosi-Zs. SzÁNTó: A gravetti időszak hagyományos és radiokarbon koradatai [Traditional and radiocarbon dates of the Gravettian period]. ArchÉrt 128 (2003) 5-16.

= M. FöLDVÁRI: Analysis of the amber from Mogyorósbánya. ComArchHung 1992, 16-17.

= C. Gamble: The Palaeolithic Settlement of Europe. Cambridge world archaeology. Cambridge, Cambridge University Press 1986.

= M. GÁBORI: Regionale Verbreitung paläolithischer Kulturen Ungarns. ActaArchHung 21 (1969) $155-165$.

= M. GÁBORI-V. GÁBORI: Les stations de loess paléolithiques de Hongrie. ActaArchHung 8 (1957) 3-117.

= V. GÁBORI-CsÁNK: Une oscillation climatique à la fin du Würm en Hongrie. ActaArchHung 30 (1978) 3-11.

= V. GÁBori-CsÁnK: La Grotte „Felső” (Superieure) et le „,Szeletien de Transdanubie”. ActaArchHung 35 (1983) 5-32.

= Gy. HAHN-Z. LobodA-B. SiskánÉ SzILAsi: The stratigraphy of loesses and terraces in Hungary. Praehistoria 3 (2002) 23-36.

= G. J. HenNig-R. GrÜN-K. BrunACKeR-M. PÉcsi: Th-230/U-234 sowie ESR-Alterbestimmungen einiger Travertine in Ungarn. EuG [Eiszeitalter und Gegenwart] 33 (1983) 9-19.

$=$ E.HERTELENDI: Radiocarbon dating of the Upper Palaeolithic site at Mogyorósbánya. ComArchHung $1992,17$.

= D. JÁnOSsY: Vertebrate fauna of site II. In: Vértesszőlős, Man, Site and Culture. Eds: M. Kretzoi, V. T. Dobosi. Budapest, Akadémiai Kiadó 1990, 187-229.

= M. JÁRAI-KOMLÓDI: A Kárpát-medence növényzetének kialakulása [Development of the vegetation in the Carpathian Basin]. Tilia 9 (2000) 1-59.

= L. KAMINSKA: Chronologische Stellung der Moustier-Funde von Horka-Ondrej im Rahmen der Zipser Travertinfundstellen. In: A la recherche de 1'Homme Prehistoire. E.R.A.U. L. 95. Liège 2000, 233-245.

= L. KAminskA-S. TomášovÁ: Time space systematics of Gravettian finds from Cejkov I. In: The Gravettian along the Danube. Eds: J. Svoboda, L. Sedláčková. The Dolní Věstonice studies 11. Brno 2004, 186-216. 
KELE et al. 2006

KoRDOS 1991

KoRDOS 1994

KORDOS-RINGER 1991

Kormos 1909

KORPÁs 2003

KOZŁOWSKI 1978

KoZŁOWSKI 1978

KOZŁOWSKI 1994

KoZŁOWSKI et al.

KROLOPP 1992

LANTOS 2004

LENGYEL 2008-2009

LENGYEL 2010

LENGYEL 2011

LENGYEL 2014

MARKÓ 2007

MiHaJlović-MiHaJlović 2013

MiHÁLY 2011

MONCEL 2001

Montet-White 1992

MonTET-WHITE- JoHNSON 1976

OSMOND 1990

PRISKIN 2011

RINGER-LENGYEL 2008-2009

RUDNER-SÜMEGI 2001
= S. Kele-A. DemÉnY-B. BajnócZi-L. Korpás-P. KovÁcs-PÁLfFy-Zs. MedZIhradszky: Paleoenvironmental evaluation of the Tata travertine complex (Hungary), based on stable isotopic and petrographic studies. AGeol 49/1 (2006) 1-31.

= L. KORDOS: A közép-európai felső-pleisztocén pocokfauna fejlődése és biosztratigráfiai értékelése (Evolution and biostratographic ranging of the late pleistocene vole fauna in Central Europe). MÁFIJ 1989 (1991) 496-523.

$=$ L. Kordos: Revised biostratigraphy of the Early Man Site at Vértesszőlős, Hungary. Courier Forschungs-Institut Senckenberg 171. Stuttgart 1994, 225-236.

= L. KORDOS-Á. RINGER: A magyarországi felső-pleisztocén Arvicolida-sztratigráfiájának klimato- és archeosztratigráfiai korrelációja (Climatostratigraphic and archaeostratigraphic correlation of Arvicolidae stratigraphy of the Late Pleitsocene in Hungary). MÁFIJ 1989 (1991) 524-533.

$=$ Kormos T. A pleisztocén ősember nyomai Tatán (Spuren des pleistozänzeitlichen Urmenschen in Tata. FtK. 39, 149-151.

= L. KoRPÁs: Édesvizi mészkövek: Új szedimentológiai modell és kronológia (OTKA zárójelentés 1999-2002) (Thermal lacustine travertines: new model and chronology). Magyar Állami Földtani Intézet, 2003. [manuscript]

= J. K. KozŁowsKi: Le Paléolithique tardif et final du bassin pannonique et des Carpates Orientales et Meridionales. AAC 18 (1978) 39-68.

= J. K. KozŁowski: The latest aurignacian and "Aurignacoid" elements in the Epigravettian of the Carpathian Basin. In: The Upper Palaeolithic Colloquium XII. A.B.A.C.O. Eds: A. Palma di Cesnola, A. Montet-White, K. Valoch. Forli, 1996, 83-92.

$=$ S. K. KozŁowsKi: The West-Carpathians and Sudeten at the end of the Upper Palaeolithic. PrehistAlp 28 (1994) 127-137.

= S. K. KozŁowski-M. PoŁtowicz-BobaK-D. BobaK-T. Terberger: New information from Maszycka Cave and the Late Glacial recolonisation of Central Europe. Quaternary International 2012, 272-273, 288-298.

= E. Krolopp: Mollusc fauna from the Palaeolithic site at Mogyorósbánya. ComArchHung 1992, 17.

$=$ M. LANTOS: Magnetostratigraphic correlation of Quaternary travertine sequences in NE Transdanubia. FtK 134/2 (2004) 227-236.

$=$ Gy. LENGYEL: Radiocarbon dates of the "Gravettien entity" in Hungary. Praehistoria 9-10 (20082009) 241-263.

$=$ Gy. Lengyel: An aspect to the re-evaluation of Ságvár (Lyukas-domb) Upper Palaeolithic site. FolArch 54 (2008-2010) 25-37.

= Gy. LENGYEL: The pebble, block and the tabular: raw material use at Ságvár. In: Emlékkönyv Violának. Tanulmányok T. Dobosi Viola tiszteletére. Eds: K. T. Biró, A. Markó. Budapest, MNM 2011. http://mek.oszk.hu/09200/09253

= GY. LENGYEL: Distant connection changes from the Early Gravettian to the Epigravettian in Hungary. In: Modes of Contact and Mobility during the Eurasian Palaeolithic. Eds: M. Otte, F. Le BrunRicalens. E.R.A.U.L. 140. Liège 2014, 331-347.

= A. Markó: The Upper Palaeolithic site at Szob. FolArch 53 (2007) 7-22.

= D. Minajlović-B. Minajlović: Serbia. In: Le paléolithique superieur Européen. Bilan quinquennia 2006-2011. Ed. P. Noiret. E.R.A.U.L. 130. Liège 2013, 27-29.

= J. MıHÁLY: Mogyorósbánya-Újfalusi-dombok felsőpaleolit lelőhelyről származó okkerkavics illetve lösz-okker porminták FTIR és FT-RAMAN vizsgálata [FTIR and FT-RAMAN analysis of the ochre samples collected on Mosgyorósbánya-Újfalusi dombok Upper Palaeolithic site]. ComArchHung 2011, 554-557.

= M-H. MonCEL: A technological approach of a microlithic assemblage: the site of Tata (Middle Palaeolithic, Hungary). ArchÉrt 126 (2001) 75-98.

= A. Montet-White: Paleolithic settlement patterns in Northern Bosnia. PreistAlp 90 (1992) 91-102.

= A. Montet-White-A. B. Johnson: Kadar: Late Gravettian site in Northern Bosnia, Yugoslavia. JFA 3 (1976) 407-424.

= J. K. Osmond: Th230/U234 dating of Vértesszőlős. Ín: Vértesszőlős, Man, Site and Culture. Eds: M. Kretzoi, V. T. Dobosi Budapest, Akadémiai Kiadó 1990, 545.

= A. PRISKIN: Jászfelsőszentgyörgy-Szúnyogos és Székes dülő felső paleolit lelőhelyek pattintott kőeszköz anyaga (tipológia és nyersanyag felhasználás) [Chipped stone tool-kit of Jászfelsőszentgyörgy-Szúnyogos and Székesdűlő Upper Palaeolithic sites. Typology and raw-material utilization]. Thesis. PTE BTK Pécs 2011.

= Á. Ringer-Gy. Lengyel: The Upper Palaeolithic site at Budapest, Corvin tér. Praehistoria 9-10 (2008-2009) 205-211.

= E. RUDNER-P. SÜMEGI: Recurring taiga forest steppe habitats in the Carpathian Basin in the Upper Wechselian. Quaternary International 76/77 (2002) 177-189. 
RUSZKICZAY-RÜDIGER-BRADÁK 2005

RUSZKICZAY-RÜDIGER 2011

SCHWARCZ-LATHAM 1990

SCHWARCZ-SKOFLEK 1982

SIMÁN 1990-1991

STREET-TERBERGER 1999

SÜMEGI-RUDNER 2001

SÜMEGI 2005

SvOBODA 2004

SvobodA-NovÁK 2004

TERBERGER 2013

VALOCH 1984

VARGA-MÁTHÉ 1990

VERPOORTE 2004

VÉRTES 1960

VÉRTES-DOBOSI 1990

VRIES-WAARD 1964

VÖRÖS 1993

VÖRÖS 2000

VÖRÖS 2003-2004
= Zs. RusZKICZAY-RÜDIGER-B. BRADÁK: Tata, Porhanyóbánya - az utolsó interglaciális időszak kimutatása szedimentológiai és mágnesezhetőségi vizsgálatok együttes alkalmazásával (Joint application of sedimentology and magnetic susceptibility in the study of the last intergalcial period, Tata Porhanyóbánya, Hungary.) FtK 135/2 (2005) 193-208.

= Zs.RUSZKICZAY-RÜDIGER: Mogyorósbánya, Újfalusi-dombok paleolit lelőhely szedimentológiai viszonyai [Sedimentological conditions of the Mogyorósbánya, Újfalusi dombok Paleolithic site]. ComArchHung 2011, 549-553.

= H. P. SchwARCZ-A. G. LATHAM: Absolute age determination of travertines from Vértesszőlős. In: Vértesszőlős, Man, Site, and Culture. Eds: M. Kretzoi, V. T. Dobosi. Budapest, Akadémiai Kiadó 1990, 549-552.

= H. P. SCHWARCZ - I. SKofleK: New data for the Tata, Hungary, archaeological site. Nature 295, 18. Febr. 1982, 590-591.

$=\mathrm{K}$. SimÁn: Some features of populational fluctuations in Europe between 50 to 15 thousand BP. Antaeus 19-20 (1990-1991) 11-17.

= M. Street-T. Terberger: The last Pleniglacial and the human settlement of Central Europe: new information from the Rhineland site of Wiesbaden-Igstadt. Antiquity 73 (1999) 259-272.

= P. SÜMEGI-Z. E. RUDNER: In situ charcoal fragments: as remains of natural wild fires in the Upper Würm of the Carpathian Basin. Quaternary International 76/77 (2001) 165-176.

= P. SüMEGI: Loess and Upper Paleolithic Environment in Hungary. An Introduction to the environmental history of Hungary. Nagykovácsi, Aurea 2005.

$=$ J. SvobodA: Afterwords: The Pavlovian as a part of the Gravettian mosaic. In: The Gravettian along the Danube. Eds: J. Svoboda, L. Sedláčková. The Dolní Vestonice studies 11. Brno 2004, 283-297.

= J. SvobodA-M. NovÁK: Eastern Central Europe after the Upper Pleniglacial: changing point of observation. AKorr 34 (2004) 463-477.

$=\mathrm{T}$. Terberger: Le Dernier Maximum glaciaire entre le Rhin et le Danube, un réexamen critique. Le paléolithique superieur ancien de l'Europe du Nord-Ouest. Mémoire de la Société Préhistorique Française 56 (2013) 1-29.

= K. VALOCH: Le Taubachien, sa Geochronologie, Paléoécologie et Paléoethnologie. L'Anthropologie 88 (1984) 193-208.

= K. VARGA-MÁthé: Petrographic analysis of the lithic raw materials of the Vértesszőlös implements. In: Vértesszőlős, Man, Site, and Culture. Eds: M. Kretzoi, V. T. Dobosi. Budapest, Akadémiai Kiadó 1990, 287-299.

= A. VERPOORTE: Eastern Central Europe during the Pleniglacial. Antiquity 78 (2004) 257-266.

= L. VÉRTES: Die Altsteinzeit der südlichen Donaugebiete. Quartär 12 (1960) 53-105.

= L.VÉRTES-V. T. DOBOsI: Fireplaces of the settlement. In: Vértesszőlös, Man, Site and Culture. Eds:

M. Kretzoi, V. T. Dobosi. Budapest, Akadémiai Kiadó 1990, 519-521.

$=$ H. DE VRIES-H. DE WAARD: Die Untersuchungen des C-14-Laboratoriums zu Groninegm. In: Tata, eine mittelpaläolithische Travertinsiedlung in Ungarn. Ed.: L. Vértes. Budapest 1964, 35-36.

= I. VöRös: Animal remains from the Upper Palaeolithic hunter's campsite JászfelsőszentgyörgySzúnyogos. Tisicum 8 (1993) 77-78.

= I. VöRÖs: Macro-mammal remains in Hungarian Upper Pleistocene sites. In: V. T. Dobosi (ed.): Bodrogkeresztur-Henye, (NE-Hungary) Upper Palaelithic Site. Budapest, Magyar Nemzeti Múzeum 2000, 183-212.

= I. VÖRÖs: Biochronology of fossil Elephantidae in Hungary. FolArch 51 (2001-2004) 9-28. 